\title{
Transatlantica
}

Revue d'études américaines. American Studies Journal

\section{The Businessman as Artist: The Subject Itself}

John Dean

\section{OpenEdition}

\section{Journals}

Édition électronique

URL : https://journals.openedition.org/transatlantica/5174

DOI : 10.4000/transatlantica.5174

ISSN : 1765-2766

Éditeur

Association française d'Etudes Américaines (AFEA)

Référence électronique

John Dean, «The Businessman as Artist: The Subject Itself », Transatlantica [En ligne], 2 | 2010, mis en ligne le 15 avril 2011, consulté le 02 février 2023. URL : http://journals.openedition.org/transatlantica/ 5174 ; DOI : https://doi.org/10.4000/transatlantica.5174

Ce document a été généré automatiquement le 2 février 2023.

\section{(c) (i) (9)}

Creative Commons - Attribution - Pas d'Utilisation Commerciale - Pas de Modification 4.0 International - CC BY-NC-ND 4.0

https://creativecommons.org/licenses/by-nc-nd/4.0/ 


\title{
The Businessman as Artist: The Subject Itself
}

\author{
John Dean
}

\section{Take The Measure}

\section{Creating, Producing, Creating}

1 Why care about what the businessman and the artist have to do with one another? Because it is a relation that puts at issue the doer and the thinker, the realist and idealist, the pragmatist and the dreamer. And a rock basic question like: which comes first, money or creativity?

2 When Harry B. and Jack Warner corralled, nursed, pampered, bullied and produced artistic output at their studios from the 1920s onward, were they just puppet masters puling the strings of people's contracts and salaries or were they in the business of creating stars and cinematic masterpieces?

3 US film production and many other businesses are laced with a history of managers who were as involved as the film's director or editor in shaping the final form and content of a movie. And what about the other arts? Buffet the subject. Develop a feel for the case. The cinema industry offers one range of illustrations about our object of inquiry. One needs to take a variety of soundings into how artist and artistry are more than a matter of one person alone. How the authority, enlightenment and impudence of art is more than the romance of individual progress, an all-holy of holies individuum ineffabile, a thing of purity that flourishes on "ranches of isolation" and "makes nothing happen: it survives / In the valley of its making where Executives / Would never want to tamper." ${ }^{1}$ No. the business-art relation is more vital, ordinary, and remarkable than this.

4 For making is also a verb in concert, a team energy of diffusion, and the matter of a business that needs to corral an audience. The screenwriter Nunnaly Johnson said of US production executive Darryl Zanuck: "His greatest value, his greatest talent was that he 
could read a script" and coach the screenwriter to "what could be done to improve it." 2 One result was the superb movie Grapes of Wrath (1940), which John Ford directed-but then "went to Honolulu, [while] Zanuck supervised the cutting, ordered the movie released" and arranged its critical reception. ${ }^{3}$ The result is a monument of American art. And business.

5 Was Memphis, Tennessee's Sun Records in the 1950s all about Carl Perkins, Roy Orbison, Elvis Presley and Johnny Cash cutting their first songs? What about Sun's producer Sam Phillips who mixed their music and decided which takes to release? Or John Hammond, Phil Spector, George Martin, Ahmet Ertegun, Quincy Jones-who were each big links in the chain that chimes into US popular music. ${ }^{4}$ Ertegun, for one, blended producing with song writing, authored the 1950s R\&B hits "Chains of Love" and "Sweet Sixteen", plus was culturally triangular-a Muslim himself, he'd work a lot with Jewish producers like Jerry Wexler, and together in turn they produced AfricanAmerican artists like Aretha Franklin. Or look at US publishing during the era of editors Maxwell Perkins at Charles Scribner's Sons or Harold Ross at The New Yorker. Wasn't the editor a professional man of business who licked and kicked lion cubs into shape? Without whom the works of Hemingway, Fitzgerald, and Thomas Wolfe at Scribner's or James Thurber, E. B. White, and Dorothy Parker at The New Yorker would not have existed? ${ }^{5}$

6 The issue of the businessman as artist is the history of ideas at work in the practise of making things. How and why the businessman as artist is the man or woman in American history who made creativity happen. Not abstraction in the formation of concepts, but material reality in the construction of the meaningful objects of music, dance, painting, sculpture, architecture, literature and cinema. ${ }^{6}$

\section{Craft and Art}

7 Nor is this only a matter of collaborations, coaching, and partnerships. The businessman as artist also includes the fundamental issues of the craftsman as artist, of craft as art, of business likewise as art which is profitable and useful because a thing well made, well tended, productive and stimulated by sales and distribution may be an art in itself. The cultural anthropologist George Vaillant explained this value well when he wrote how "craftsmanship allows an exercise of the creative impulse, satisfying the individual through his domination of the raw material," for with well-done craft work a person does not feel that sensation "of having cut himself from the tree of natural existence with the saw of his own reason." Craft may qualify the real chair, table, wallpaper, window or daily piece of pottery to art.

8 Consider one outstanding US record of indigenous craft achievement in material culture: the brilliant chronicle of craft art in The Index of American Design (1950), a late flowering of the New Deal years which bears witness to the businessman as artist. ${ }^{8}$ Produced for the masses doesn't ipso facto mean crass produced and grossly consumed. Nor is craft as art a quality disappeared. It has continued in America through the decades and down to the present time; sometimes "industrialized" and sometimes not. ${ }^{9}$

The business of making art is an acquired skill. The elitist European art academy in the United States developed into an American training ground to make and sell. For art and design this phenomenon stretches back at least to the Yale University Art School which trained that great businessman-artist of the old American West Frederick Remington 
(1861-1909) through a series of schools such as Cranbrook Academy of Art in Michigan and Rhode Island School of Design. For writing this blend was pioneered by such institutions as Black Mountain College near Ashville, North Carolina, beginning in the 1930s through the USC's current Ph.D. program in literature and creative writing or Portland Community College's program in creative nonfiction. All this in contrast to the European tradition of art having to depend on government funding; updated aristocratic patronage. ${ }^{10}$

\section{The Arnold J. Toynbee Argument} been visible in US industry throughout a wide range of technologies and technological leaders, arts and commerce. This is not to say that all businessmen are artists. But rather to argue that the characteristic values, liberties, freedoms, individualism and market needs in American civilization have allowed and encouraged many outstanding figures who blend business with art.

11 To see this fact one has to think and explore outside the boxed, standard divisions of business versus art, commerce versus creativity, the "conflict between art as personal expression and art as commerce", commercial viability versus canonized respectability. ${ }^{11}$ One has to go beyond the older academic ideal that the "element of art is superadded to that of utility [...] The element of art is isolated [...] This element [...] is itself a product of human activity particularly free and disinterested, the object of which is not to supply an immediate need, but to evoke a sentiment, a lively emotion-admiration, pleasure, curiosity, sometimes even terror." ${ }^{12}$ By virtue of this older, idealized argument, art exists only "under the dual aspect of a luxury and a diversion" ${ }^{13}$ Art cannot be a tool, the outcome of need or necessity. and intellectual action from those who chose it. The more remarkable is the person who made the choice. It's not that the art they produce is better. It's that they are another kind of artist. A diligent maker who manages the process. Toynbee identifies each of his examples of artistic free will as a "hero of the life of intellectual action" (Toynbee, 17). than an activity that's been thrown upon one by the necessity of personal distress. "He only earns his freedom and exists," wrote Goethe in Faust, Part Two, "who daily conquers them anew." Thus Toynbee offered the unorthodox argument that Edward Clarendon, Polybius, Dante Aighieri, Machiavelli, Confucius, Saint Gregory the Great, Saint Ignatius Loyola, Thucydides, Xenophon, Muhammad and Solon were less remarkable as individuals-because they took to their individual arts as a last resort, a last resource "to occupy an enforced and unwelcome vacation from some 'practical' activity" (Toyneee, 7). They were less remarkable in their human career as creators than the practical men of free choice, such as George Grote (1794-1871), John Stuart Mill (1806-1873), Heinrich Schliemann (1822-1890), James Bryce (1838-1922), James Ford 
Rhodes (1848-1927) $)^{15}$-and some of the men and women noted in this Transatlantica dossier.

According to Toynbee, practical affairs are an effective apprenticeship for the creative life. Why? Because creativity is both a life of action and demands that a person must master clear, concise communication. As philosopher and political economist John Stuart Mill wrote about his valuable experience working at India House: "I became practically conversant with [...] the art of sacrificing the non-essential to preserve the essential" (Toynbee, 25). ${ }^{16}$ The keynote is discipline. They persisted in the pursuit of long-term creative objectives; with steadfast patience achieved their goal.

The Toynbee pattern has wide appeal and application. One example he did not give is Theodore Dreiser's Cowperwood-Yerkes figure in Dreiser's semi-documentary Cowperwood trilogy-The Financier (1912), The Titan (1914), The Stoic (1945)-which deeply examined the nature of an innovative baron of American business. ${ }^{17}$ In Dreiser's trilogy the hero's art combined his remarkable synthesis of skilfully inventive, intuitive ways to make money, his excellent, unschooled taste as a patron and collector of fine paintings, and his Don Juan conquests of only the most beautiful women. Dreiser argued that there's a certain creative flamboyance about making money, a liberation of ego and libido, and-as many a contemporary economist has argued amid our deep economic crisis of the early $21^{\text {st }}$ Century-an exceptional amount of flash and agility that comes naturally to the successful businessman or woman since "markets behave irrationally". ${ }^{18}$ Dreiser's hero-his Cowperwood-Yerkes figure-is a great businessman as artist because he always acts in his own best interest, and knows theory is useful only after the deal has been made.

\section{Supply and Demand: Marxist Theology}

The producer, the craftsman, the training, the Toynbee argument-then there's the Cold War viewpoint on art and action from the ideologues of Marxism.

Art was understood in that ideological context as a powerful social tool either abused by capitalism or used for the good of the utopian state-the promise of transcendent harmony for all mankind. From the Marxist perspective art was scientifically positivistic, hence deterministic upon its audience. As Joseph Stalin declared, "an artist is an engineer of the human soul". ${ }^{19}$ Simplistic? This is the classic one-on-one injection theory of art and society which argues for little or no individualism in the audience. Art provides belonging as opposed to difference, individual satisfaction as opposed to individual independence, union rather than alienation. A force one finds in youth culture art in America and elsewhere before, during and long after the Cold War.

Vladimir Lenin provided a more nuanced interpretation. He declared that art-using Tolstoy as his example-neither reflects nor directly expresses the "experiences of social life: this expression is mediated by encounters with ideologies and contradictions which arise from it." ${ }^{20}$ In Marxist terms, art serves revolutionary transition.

When Marxist theoretician Herbert Marcuse witnessed America of the post-WWII years the communist puritanism of his soul was shocked by the freedoms of the capitalist state. America's social and economic organization produced a culture that was a "world of necessity [...] inconstant, insecure," argued Marcuse, in which "wealth and wellbeing do not come or persist due to [...] autonomous decision but through the changeable fortune of opaque circumstances. ${ }^{21}$ Business and art flourished in lucrative 
partnership in the rampant materialism of the American bourgeois state, nourishing conditions of spiritual disorder and demeaning exploitation. The path to follow was awareness of alienation, false needs, and the pursuit of liberation.

In sum-considering the immense theology of Marxism-is it not fair to say that from the Marxist viewpoint the art-business relation was secondary to more powerful forces of economics and materialism? Art is ideology. It served either the dominant class or the proletariat (or the state for the sake of the proletariat). The bourgeois artist was a businessman whose stock and trade was manipulating human desires to perpetuate capitalism. Of course the artist was a businessman. And vica versa.

But couldn't he or she be more?

\section{Art in the Age of American Mass Production}

The businessman as artist has been specially visible in the United States amid the "extraordinary constellation of sociologically and economically significant new technologies developed in the twentieth century centering on personal and mass entertainment." ${ }^{22}$ The title of Walter Benjamin's ground-breaking, 1935 essay should not have been "The Work of Art in the Age of Mechanical Reproduction" but "Art in the Age of American Mass Production". Since the American audience has above all lived in an environment of mass production and consumption way beyond the boundaries ever dreamed of by Benjamin.

The five entertainment technologies created from the late $19^{\text {th }}$ through the late $20^{\text {th }}$ centuries which facilitated a conspicuously huge US blend of production, profit, and artistic creativity were radio, movies, recorded music, television, and the internet. These five interacting technologies together and individually illustrate how the medium is the message, the medium is the massage, and the medium is the messenger.

With U.S. TV, for example, Mary Tyler Moore (1936- ) came to personify the best of her industry. Both in her lead role in The Dick Van Dyke Show (1961-1966, CBS) and The Mary Tyler Moore Show (1970-1977, CBS; rated for six years in the Top 20) she was a breakthrough role model for American women.

On prime time US TV, Mary Tyler Moore's characters of Laurie Petrie and Mary Richards personified the nation's new independent female who spoke her own mind and did her own thing. Soon to be shown as well in the 1988 Mike Nichols' film Working Girl. She was successful at her job and a powerhouse of vital humor. At the height of her career Moore's media company MTM (Mary Tyler Moore Productions) was a positive, flourishing, enlightening example of US TV "edutainment". ${ }^{23}$

But now, by the second decade of the $21^{\text {st }}$ century, Mary Tyler Moore is ancient media history. Because in the USA obsolescence happens quicker than elsewhere. The audience is more deeply segmented by generational tastes (hence, generation) and rapid consumption; One expression of this is how popular culture studies now flourish in US higher education, but rarely Cultural History-which has to do with the long past rather than today's news. Hence flavor of the week becomes critical study of the year. 


\section{The Go-between and What's Between}

Since the advent of art in the age of American mass production the relation of business to art has been dramatically important. Rembrandt van Rijn and Vincent Van Gogh had their dealers Hendrick van Uylenburgh and Cornelis Van Gogh. But their paintings could not be distributed and sold by the millions. In our age the unique has multiplied. The line has blurred between the go-between and what's between.

US culture has gone a long way to show how art is bigger than the traditionally high, European fine arts of painting and sculpture, classical music and dance, architecture and literature. Form and content, package and product, creation, diffusion and delivery make up a long narrative line. Franklin Delano Roosevelt pointed this out in his radio broadcast that opened New York's Museum of Modern Art in 1939-how art by US measure means "photography, the printed book, the illustration, the advertisement, the poster, the theater [...] the moving picture [...] industrial design, architecture, [and] the great social art-housing." ${ }^{24}$ And so much more.

The following overview of the subject itself will try to trace business and art through a number of high and low byways of principles and practices in European and American civilization. The subject is admittedly huge and one cannot begin to exhaust it. But hopefully an informative review of issues can be displayed. The attempted objective here is to provide a better understanding of the businessman as artist in Western Civilization in general,Anglo-American sensibilities in particular, and why the businessman as artist relation is specially dominant in US Civilization. ${ }^{25}$

\section{Tease Out the Arguments}

\section{Freaks: Alexis de Tocqueville and P. T. Barnum}

2 Identity is continuity over time. But it is also how the changing times shape identity. Our lives as individuals, professionals, and members of a nation are simultaneously active and reactive. From Alexis de Tocqueville (1805-1859) through H. G. Wells (1866-1946) in the $19^{\text {th }}$ and early $20^{\text {th }}$ centuries, various foreign visitors to the USA were struck by the exceptional nature of America as a business culture and how the nature and occupation of art was altered by business.

33 De Tocqueville thought high art, ideal art, by makers who "always do all they can; and when they stop, it is because they have reached the limit of their art" was debased to a "state of accomplished mediocrity" in America. The demands of business were too great and too profitable. And so in the US "the productions of the arts are generally of an inferior quality, very abundant, and very cheap." ${ }^{26}$

34 Maybe de Tocqueville was experiencing culture shock. Art in America wasn't an elite ideal imposed from on high by blue-blooded, aristocratic patrons. Strange new freedoms were at work in American art. New relations had developed and been visibly declared; a democratic taste culture and its suppliers which allowed new license of expression and consumption. Baptized anew in American circumstances, business slowly redefined art.

An entrepreneurialism was in the air of the time that encouraged businessmen to do art. In Europe in 1786 Mozart had written the opera The Impresario (Der 
Schauspieldirektor, K 486) which singled out a new type of businessman who managed, produced, and shaped extraordinary talents. The promoter, theater producer, arts manager, agent, creative entrepreneur and impresario, however labelled, were coming of age. In the early 1790s Joseph Haydn wrote his symphonies 93 to 104-"Salomon Symphonies"-after the impresario who had arranged his London tours, Johan Peter Salomon (1745-1815), who was also an accomplished conductor, violinist, and composer.

People in Anglo-American entertainment by the 1800s even referred to an impresario as an "angel"-a miraculously necessary go-between who had divine powers. ${ }^{27}$

Did de Tocqueville in his American travels ever cross the path of the USA's great impresario P. T. Barnum (1810-1891)? If so, what strange new freedoms of expression did he see or ignore?

Back in France physicians, philosophers, and notably the teratologist Geoffroy SaintHilaire (1805-1861), had recognized and busily classified nature's abnormalities. SaintHilaire neatly organized freaks of nature into six distinct categories of monsters for better understanding, but not for delight. ${ }^{28}$ Popular broadsides, pamphlets and street exhibits in Europe displayed monstrous deformations as a sign of divine punishments and warnings. Educated classes in Europe thought these displays were disgusting proof of popular ignorance and superstition. They were worse than accomplished mediocrity, they were vulgar. ${ }^{29}$

But in America of the 1830s and 1840s the businessman P. T. Barnum made an art out of freaks. For the US audience freaks were revelations of the secret self. They evoked terror, fascination and natural sympathy. (Has the reader never dreamed of his or her self as freakish? Let he who is without guilt cast the first stone.) Plus Barnums' freaks had a job to do for the overall organization of the circus business. Like Wall-Mart "greeters" later on, the freaks pulled in customers to the main show and helped to boost sales. Barnum's freak show art challenged the "conventional boundaries between male and female, sexed and sexless, animal and human, large and small, self and other, and consequently between reality and illusion, experience and fantasy, fact and myth." 30

If Barnum's goods had been right before de Tocqueville's eyes, would the aristocratic French journalist even have looked? How could a freak show-US circus family entertainment from the 1830s through the 1950s in most of the United States-have possibly fit De Tocqueville's high definition of art or entertainment? But then American civilization had a way of pushing frontiers. ${ }^{31}$

\section{Herman Melville and Andrew Jackson}

41 The US Jacksonian and Antebellum eras were ripe for change. From the mountain men in the far West to the new generation of urban social reformers in the East, the Jacksonian era in particular recalibrated human relationships. One aspect of this development was how creative managers learned to tap into the popular and sell, and how the audience itself gained power and respect.

At this time American theater, opera, and classical music audiences were extremely eclectic, proudly independent, openly judged what they received against what they had been promised. Art was democratized. Thrown off balance by new money and the need 
for status objects and conspicuous consumption after the US Civil War (1861-1865), art would then become elitist for over a century in the USA. It would eventually be redemocratized in the 1960s. ${ }^{32}$ Though at all times in America the democratic audience would be alive and well in the areas of sports and religion. ${ }^{33}$

Changed relations came about in the Jacksonian and Antebellum eras partly because of new political leadership that allowed a break from old aristocratic traditions, partly because a remarkable group of charismatic, creative businessmen in many American fields of industry had appeared, and no little because of the vitality of the US democratic audience. As the king and the duke learned only too well in Mark Twain's The Adventures of Huckleberry Finn (1885) which recorded this era-the audience, the public, and the baboozeled citizenry could fight back: "they had the king and the duke astraddle of a rail [...] they was all over tar and feathers, and didn't look like nothing in the world that was human-just looked like a couple of monstrous big soldierplumes." ${ }^{34}$

Consider Herman Melville's Moby Dick (1851). Like the writings of the US Beatniks a century later in the 1940s and 50s, Melville's text is both a social and an aesthetic document. It registers an American reality and sentiment. Much of Melville's concern was with the state of American mankind. He was acutely aware of the demeaning bulk and body of humans when lumped together in an indistinguishable whole. From the fictional agony of his short story "Bartleby the Scrivner" (1856) through his own last two decades of life as a poorly paid district inspector of customs in teeming New York City, Melville's life work registered an acute conflict between mass and individual, a debased ordinary and an exalted extraordinary at tension in American life.

Melville had a truly hot-blooded Jacksonian temperament. After his success with his South Seas adventure novels Typee (1846) and Omoo (1947), he fancied himself the master of his market. He impulsively created the idiosyncratically brilliant Moby Dickthe greatest failure of a sea tale ever written-and incidentally illuminated a key to American artistic quality. Melville saw a link between mass and popular which the European elitist de Tocqueville was incapable of making. (De Tocqueville who had so recently declared in the 1840 s that there must be an "absence of great writers in America," since "literary genius cannot exist without freedom of the spirit, and there is no freedom of the spirit in America. ${ }^{35}$ Then, in the light of his dogmatic declaration, Moby Dick was created!)

46 American life offered a potent new mix of the ordinary and the extraordinary. The key to this blend was the Jacksonian spirit, the ability to trust-in Andrew Jackson's words - "to the virtue of the people, the real people, not the politicians and demagogues," to be "sustained by the bone and sinew of the nation, the laborers of the land, where alone [...] real virtue and love of liberty is to be found." ${ }^{36}$

Neither Andrew Jackson nor Herman Melville were soft on working men and women as romantic ideals or as a wimpy, whispy, Wordsworthian "leech-gatherer on the lonely moor." ${ }^{37}$ It was the independence, common sense, hearty resilience, the boisterous and sometimes outlandish vitality that came of age at the time of Andrew Jackson, along with a rebirth of the popular, national self-" the bone and sinew of the country-men who love liberty and desire nothing but equal rights and equal laws" 38 -that Melville rooted for. But always in a state of tension, a mass-popular tension.

When Melville evaluated the common American crew on the corporate whaling ship Pequod in Moby Dick, he pointed out how on the one hand "men may seem detestable as 
joint stock-companies", but the "meanest mariners, and renegades and castaways [...] even the most mournful [or] abased among them all, shall at times lift himself to the exalted mounts," and be touched "with some ethereal light"-as did "Andrew Jackson [whom] [...] thou great democratic God [...] didst hurl [...] upon a warhorse [...] didst thunder him higher than a throne!" ${ }^{39}$

In a later scene in Moby Dick, where the narrator is considering the carpenter of the whaling ship Pequod, Melville notes through the character of Ishmae: "Seat thyself sultanically among the moons of Saturn, and take high abstracted man alone; and he seems a wonder, a grandeur, and a woe. But from the same point take mankind in mass, and for the most part, they seem a mob of unnecessary duplicates, both contemporary and hereditary." Yet not so the Pequod's ordinary carpenter, this working man, this man of the people, though he did not furnish "an example of the high, humane abstraction"-yet "he was no duplicate". ${ }^{40}$

Melville bears witness to a divided consciousness in Moby Dick, this business trip turned into an all-American quest for meaning. Worry about the mass. After all, the mass carries you, includes you. "It's a mutual, joint-stock world." ${ }^{41}$ But at what cost? For "now merged in a joint stock company of two [...] my free will had received a mortal wound; and [...] another's mistake or misfortune might plunge innocent me into unmerited disaster and death". ${ }^{42}$ Melville insists how-along with the joint-stock world-there is also a free, solitary, creative, zone which is off-limits to the crowd, to the corporations and to the state. America offers liberty, but freedom belongs to the individual.

Melville's whaling epic distinguishes between two necessarily interdependent forces: businessmen and visionaries, corporate profit and team effort along with various human odds and ends, monomaniac Ahab, contemplative Ishmael, and the exceptional carpenter who provides the final life raft. According to Melville the outcome of this combination of businessmen and visionaries is tragic. But need it be?

This creative political zone of individual expression first came of age in the Jacksonian era following the war of 1812 and saw the wholesale application of the theory "that one person is as well qualified as another to perform the duties of an office," that education diffuses knowledge and that knowledge is power, and that the business of America and common Americans is enriched by art. ${ }^{43}$ Melville's craftsman carpenter is such an artist. His failure is the tragedy of his leader, Captain Ahab.

Just as Andrew Jackson would denationalize and regionalize the US banking system, so the cultural wealth of America would be redistributed. Exclusive privileges of the wealthy would be limited. The popular arts would develop from the status of commercial articles of trade and commerce to dime museums and freak shows, and over time to ornate, mass-produced works of beauty, insight, aesthetic value and cunning communication.

It would take about a century before legal recognition of some of the nation's most characteristic businesses would be recognized as art (like the movies, that were legally and ethically classified as business and not art in America from 1915 to $1952^{44}$ ). But due to America's business spirit, art production and popular appreciation over time replaced artistic aura. And thereby the boundaries of art were extended, the commonwealth of art was enriched. 
56 To background how this first happened, one should turn to the $19^{\text {th }}$ century debate about business and art.

\section{Contrasts and complements}

57 Thomas Carlyle (1795-1881), Ralph Waldo Emerson (1803-1882), and Jacob Burkhardt (1818-1897) were three of the great modern pathfinder thinkers about the issue of businessman and artist at the onset of the Industrial Age. To get this matter straight one can profitably consider their deep meditations as a representative variety of opening definitions.

In general, Carlyle, Emerson, and Burckhardt answered the question of how businessman and artist relate in terms of cross-tribal dialogues between two cohort groups who possess different core values and perform complementary or opposed social functions. Each gave their eloquent, definitive close readings of the businessman and artist in the spirit of their Victorian Age which arrogantly distinguished culture as class and defined art as the privilege of a wealthy or educated elite. ${ }^{45}$ But their individual sense of the relation, the distance, and the intertwining between businessman and artist differed. Carlyle envisioned a political harmony which did not yet exist. Emerson romanticized art as a holy, hobbled weakling compared to business. While Burckhardt believed art and business made a perfectly fine match when the time was right.

In Past and Present (1834) Carlyle summed up the contrast between businessman and artist as the difference between "Aristocracy and Priesthood, a Governing Class and a Teaching Class". In his brassy tone, Carlyle, that drill sergeant of ideas, declared: "The Leaders of Industry [...] are virtually the Captains of the World; if there be no nobleness in them, there will never be an Aristocracy more"-while great artists and "Literary men are [...] a perpetual priesthood." 46 But Carlyle's text was tinged with desperation. He had Walt Whitman's visionary force and manly independence without Whitman's contagious optimism.

60 Carlyle was not praising the "cash-obsessed modern businessman" driven by economic imperatives who feared "the Hell of not making money". ${ }^{47} \mathrm{He}$ never came remotely near imagining a noble British Willy Loman figure. Carlyle was straining to bind the practical and spiritual by envisioning a better upper class than his own contemporary British "landed aristocracy, still interested only in shooting their partridges." ${ }^{48} \mathrm{He}$ prophesied an elite union of businessman and artist which did not yet exist in England -though William Morris (1834-1896), Pre-Raphaelite artist and son of a successful businessman, would soon try.

61 Emerson made the point of contrast between businessman and artist even stronger in his essay "Wealth" from his 1860 collection The Conduct of Life written on the brink of the Civil War and the North's subsequent spectacular industrial growth. "Art is a jealous mistress," wrote Emerson, and "if a man have a genius for painting, poetry, music [...] he makes a bad husband, and an ill provider, and should be wise in season, and not fetter himself with duties which will embitter his days, and spoil him for his proper work." ${ }^{49}$ For Emerson in "Wealth" the proper work of most men-specially Americans-was that "every man is a consumer, and ought to be a producer." ${ }^{50}$ There is no better producer than the man of practical affairs, no worse than the artist. He held up his own youthful experience of the Brook Farm utopian fiasco of 1841-1847 as an 
example. For the "genius of reading and gardening are antagonistic," argued Emerson, since the first "is concentrative in sparks and shocks: the other is diffuse strength; so that each disqualifies its workman for the other's duties." ${ }^{51}$

Rife here was the age-old Platonic ideal of art; specifically neo-Platonic for the Unitarian Reverend Ralph Waldo Emerson whose subtext in "Wealth" was Christian faith. For "no man can serve two masters: for either he will hate the one, and love the other; or else he will hold to the one, and despise the other. Ye cannot serve God and mammon." ${ }^{2}$ This romantic, religious argument long held sway, as debated both in the United States and Europe-and remains persistent in the conflicting attitudes of both high-brow culture addicts and low-brow fans.

\section{Wheel within wheels: the lingering ideal of "Art"}

Subtext for Emerson's subtext is the true nature of art worried over since the time of Plato and Aristotle in Western thought. From the Lascaux cave paintings and Romanesque cathedrals to the mysticism of modern religious verse, art has been idealized as a sacred medium between people and their divinity. Specially for the initiated. "Is it possible for the multitude to understand the reality of beauty itself?" Socrates asked rhetorically about art and philosophy in Plato's The Republic. A statement which was quickly given the reply: "The love of wisdom is impossible for the multitude. Impossible." ${ }^{3}$

Further down the road in the same perfect rut lay the European social historian Bertrand de Jouvenal who argued in the early 1950s for an inevitable state of conflict between the businessman and the artist because a businessman is committed by the law of supply and demand to give the customers what they want. Hence the businessman, de Jouvenal observed, must be at the customer's mercy since the customer is always right. Conversely, an artist exists free of all markets and must view the "worth of his product independently of their immediate market value." ${ }^{54} \mathrm{De}$ Jouvenal echoed the Christian subtext from Christ's Sermon on the Mount: one cannot serve art and commerce, God and mammon both.

W. H. Auden, that charming, Anglo-American grotesque of a man gifted with a mellifluous voice and a face textured like a dried prune as he grew older, argued in his late, coruscating book The Dyer's Hand \& Other Essays (1963), that true art "is very nearly a Utopia". It must be so since art guards "that paradisial state in which Freedom and Law, System and Order are united in harmony." ${ }^{55}$ This notion was stated earlier in Auden's own deadly remarkable poem "In Memory of W. B. Yeats" (1949). Wherein Auden insisted that art exists on "ranches of isolation" amid its raw towns of busy griefs." ${ }^{.66}$ As it must, since art has otherwise been so bastardized and bowdlerized in modern times. It's become the titillating whore of business interests from which "the mass media must steal [...] if they are not to go bankrupt." ${ }^{57}$ For "what the mass media offers is not popular art, but entertainment which is intended to be consumed like food, forgotten, and replaced by a new dish." ${ }^{58}$ For true art "makes nothing happen: it survives / In the valley of its making where executives / Would never want to tamper [...] it survives, / A way of happening, a mouth." 


\section{Aristotle}

66 imitation, mimesis. Art is not an ideal. It does not always present truth with a capital " $\mathrm{T}$ ". "Truth," that is, in the sense of the Platonic forms, the eide, the ideals which supposedly have an existence without spatial extension. Art is about understanding more by using reflection and reproduction.

Art is at liberty to present people either as they are or as they should be, argued Aristotle. Truth is not irreconcilable with art, but its essential business lies elsewhere: to tell stories, to serve its audience an astonishing feast of pity, fear, catharsis, to evoke man's natural instinct for harmony and rhythm, the serious and the comic, and to provide unity of a philosophical nature since art "deals more with things in a universal way, but history with each thing for itself" ${ }^{59}$ By a sudden change of events or a reversal of circumstances art leads its spectators to recognition. Tragic art in particular is the great art since it offers "an imitation of better men than our contemporaries", characters who essentially are good, appropriate, true to life, and consistent. And who die trying.

"Plato is dear to me," said Aristotle, "but dearer still is truth." Here is what Nietzsche called truth in a larger than Platonic sense-"the whole Olympus of appearance". ${ }^{60}$

\section{Back to basics, back to Burckhardt}

Jacob Burckhardt's ideas about the question of business and art were highly innovative, based on his groundbreaking study of cultural rebirth The Civilization of the Renaissance in Italy (1860). ${ }^{61}$ Burkhardt held up the example of the Italian Renaissance as an era of change from limited, medieval man to many-sided, universal man. It had happened before and it could happen again.

$70 \mathrm{He}$ analyzed this change as similar to how the individualism of the Classical Greek distinguished himself from the dominant tribal values of the barbarian hoard, and how the Umayyad "Arab had felt himself an individual at a time when other Asiatics knew themselves only as members of a race." ${ }^{62}$ The key factor here was not the cultivation of each and every individual but the rebirth of individualism itself-the personal cultivation of freedom and choice in order to achieve excellence.

71 In Florence in particular, argued Burkhardt, this phenomenon resulted in the keen development of many-sided men and women who developed this way because their immediate environment demanded both practical and theoretical knowledge from the same person. Eras occur, continued Burkhardt, where a wealth of demands are made by a time and a place upon a people, and these demands are met. In Florence from Lorenzo il Magnifico to Dante Alighieri, from Leon Battista Alberti to Leonardo da Vinci the lesson was given that "Men can do all things if they will". ${ }^{33}$ Because much was expected of them. Thus the traditional opposition between commerce and art was overcome and by 1478 Florence proudly counted the arts among its chief commodities. ${ }^{64}$

\section{Theory and practise: where businessman and artist connect}

Oddly Emerson the American was pessimistic. But Carlyle and Burckhardt the Europeans hoped that if conditions were right then business and art could form an 
alliance and broker a remarkable civilization. In full phrase Carlyle noted: "Aristocracy and Priesthood, a Governing Class and a Teaching Class: these two, sometimes separate, and endeavouring to harmonise themselves, sometimes conjoined as one [...] there did no Society exist without these two vital elements, there will none exist." ${ }^{65}$ inventor. But what's been crucial in American civilization hero as thinker per se, but as an inventor hero, an inventor thinker-and not an ineffectual intellectual. Alexander Graham Bell (1847-1922), Thomas Edison (1847-1931), Henry Ford (1863-1947), Wilbur and Orville Wright (1867-1912, 1871-1948) were understood in their time as artists of the telephone, electric power and phonograph, the automobile, and the air plane. ${ }^{68}$ intellectual abstraction. As Mark Twain wrote in Life on the Mississippi: "There is something fascinating about science. One gets such wholesale returns of conjecture out of such a trifling investment of fact." What has counted most is the people who bind think, make and do. Regarding the pantheon of Bell, Edison, Ford and the Wrights, the US 'public loved their style, saluted them as 'wizards,' and viewed their achievements as evidence that miracles were still possible-even in this modern world." ${ }^{69}$ What was specially fascinating about this touchstone generation of American inventor heroes was how they made and lost fortunes. What counted most was not the money they made from their creations, but the value of work itself, their thirst for self-expression, their doggedness, their restless dissatisfaction with the state of things, and a dynamism that got things done.

Take Henry Ford for example. Reflecting on what she witnessed in Detroit in 1915-1916 from the perspective of her autobiography All in the Day's Work (1939), the muckraking journalist and historian of American industry Ida Tarbell praised the social service work done by Ford Motor Company for its thousands of employees under the leadership of "poet and philosopher, Henry Ford." ${ }^{70}$ Tarbell measured the fact that the 
elder Ford was an outstanding example "for practical application of the Golden Rule in industry." "71 Here a sound if imperfect direction was given for how the life of American workers could be everything they ever wanted it to be.

According to Tarbell, workers were much better off because of Ford Motor Company's improvements. And, although the idealists-like James Couzens, Samuel Marquis, and the young Edsel Ford, who were the driving force behind this new movement in American industry-"could not do the thing, [yet] it could and did drive men to prove it could be done."72 In Ford's case the business had the vision to imagine a better world, even if it could not yet be fully realized. (The Detroit Industry Murals [1932-1933] produced in collaboration between Edsel Ford and Diego Rivera have much the same effect.) Reinhold Niebuhr, the German-American social scientist and theologian, who served one of his earliest congregations in Detroit in the 1920s, equally spoke of Henry Ford at this time as a poet rather than as an industrialist or businessman because of the nature of Ford's commercial creativity. ${ }^{73}$

\section{The art of success}

80 From the 19th to the early 20th centuries some outstanding Americans helped to redefine success. This had a powerful effect on the meaning and value of creativity in the culture. While previously in Europe and the United States success had traditionally meant "'wealth', 'influence', 'position' or 'prosperity'," by the end of the 19th and the beginning of the 20th century in American English success "was used and with a different connotation from the one it had before. Now success strongly suggested a personal accomplishment-non-monetary." 74

81 In America, as David M. Potter optimistically wrote in People of Plenty, Americans have a powerful compulsion to achieve success "measured not by what one possesses in wealth or position but by what one has gained; it is not attainment of a fixed goal but advancement to a higher level" which was constantly encouraged by the "opening of new areas, development of new resources, and discovery of new technological devices." 75 In effect, American civilization provided one of those rare opportunities in world history and culture noted by Burkhardt where people are given to believe they can "do all things if they will". Not everything in the United States had to be about monetary profit. Business meant more.

But how "more"? William James famously noted that the need for individual success measured by wealth and status in America was a national disease-"the bitch-goddess". ${ }^{76}$ With the growth of Corporations and the spread of "The Organization Man" in the USA's 20th \& 21st centuries business meaning more than material, corporate, get-ahead success for both men and women has been a vexing reality. And times of severe economic and social crisis have happened often enough in the United States-about fifty major economic recessions and depressions since the American Revolution ended ${ }^{77}$ -that the limits of worldly success have been repeatedly exposed.

One thing is for sure: the vertical nature of the business culture. For unlike the land's indigenous civilization of the Indian, and in spite of the land's complex natural environment and its constant reoccurence of natural and economic disastersAmericans do not have a cyclical vision. Life is upward, ever upward, progressing. Mankind is not trapped in a cycle of delight and disaster, feast and famine. America is not a fatalistic culture. There's always hope. 

extend beyond sheer materialism. One finds this in the Cowperwood/Yerkes figure in Dreiser's Cowperwood Trilogy of the early $20^{\text {th }}$ century. It's there in industrialist Edsel Ford's collaboration with Diego Rivera in 1932-1933. Present in similar but less successful attempts during the Great Depression by New York's Rockefeller family (mockingly exposed in the 1999 movie Cradle Will Rock). Evident in America's enormous corporate-and characteristic-philanthropic investments. One finds this aspiration in the stark visions of American painter Edward Hopper. Even in the mass production, love/hate gimmickry of Andy Warhol's ironic creations. Art is the great partner of business. Art makes sense of its barbarian forces.

\section{Intellectual Property}

Essential groundwork for 20th century US theory and application which reconciled businessman and artist was also laid by the visionary work of Walt Whitman. In 1855 Whitman provided the United States with an ecstatic Künstlerroman in free verse with his Leaves of Grass collection. In which Whitman argued that neither business nor poetry could reach that ideal level which is mankind. All approaches, all is an approximation of an exalted potential that started with each individual's birth. "Will we rate our prudence and business so high? [...] I have no objection, I rate them as high as the highest," Whitman wrote, adding: "but a child born of a woman and man I rate beyond all rate." 78

86 For Whitman "the sum of the profitable uses of individuals or states and of present action and grandeur" and of "prosperous business [...] farms [...] capital" was the result of "a corresponding largeness and generosity of the spirit of the citizen". Whitman praised an American genius for sheer potential which was not the property of any one profession. As a contemporary review of Whitman's work later noted: "He reads a man -the very spinal marrow of him-not as an anatomist or a psychologist, or a man of business or a tailor, but as they all would do. The separate, special individuality: that seizes Whitman's attention-and he has the man." 79 Business and poetry were equal foundation stones for the greater edifice of the civilization..$^{80}$

This spectacular generosity, this common sense sentiment would echo down the years through American Civilization. One notable recurrence, already partly noted, was Franklin D. Roosevelt's October 1939 radio broadcast for the "Art in Our Time" exhibit held at New York City's Museum of Modern Art when FDR insisted "art in America has always belonged to the people and has never been the property of an academy or a class," and how by "encouraging the creation and enjoyment of beautiful things we are furthering democracy itself." 81

Mankind seen from the American perspective of William James and Thomas Edison, the Wright brothers and Walt Whitman, Horace Mann and Franklin Delano Roosevelt is homo faber, a tool making animal-a definition first creatively offered by businessmanartist Benjamin Franklin. ${ }^{82}$ In the context of American civilization take this visionary practice one step further and both the typology and practice of businessman as artist overlap.

Each culture, each society, has a range of expectations, of allowed frames, in which their members are encouraged to become themselves. Isn't Daniel Day-Lewis' portrayal of Sinclair Lewis' hero Daniel Plainview, adapted from Lewis' novel Oil! in the 2007 
movie There Will Be Blood, a portrayal of a single-minded artist of property? The socially autistic Mark Zuckerberg of Facebook fame, as portrayed by Jeff Eisenberg in the 2010 movie The Social Network, compensates for his own profound inability to communicate by creating a device-(Facebook)-which does; with which device he and his team do things only artists "are intellectually or creatively capable of doing". ${ }^{83}$

Theodore Dreiser's Cowperwood Trilogy of the early $20^{\text {th }}$ century firmly attested to this compelling phenomenon. From his earliest days "buying and selling stocks, as [Cowperwood/Yerkes] soon learned, was an art, a subtlety, almost a psychic emotion. Suspicion, intuition, feeling-these were the things..." since "a man, a real man, must never be an agent, a tool, or a gambler-acting for himself or for others-he must employ such. A real man-a financier-was never a tool. He used tools. He created." ${ }_{84}$

91 Taking all this into account, isn't this is one reason why there's a law-an Americanism -called intellectual property? Which simultaneously covers business and art. That's calling it close.

\section{Visions}

American civilization excels at visionary business. It's the stuff the place was made of since America was imagined before it was discovered. From the time the conquistadors quested for golden El Dorado in the deserts of the South West and John Winthrop predicted his new City On A Hill amid the swamps of Boston, one finds this visionary lust; to seek what may be-even if it does not exist. One among many popular culture examples is how this visionary business throbs through American blues music. For the blues are that dark zealotry in which, as Ma Rainey says in August Wilson's Ma Rainey's Black Bottom: "You don't sing to feel better. You sing because that's a way of understanding life." ${ }^{85}$

Or take the American movie business as an indigenous, visionary industry that melds business and art, a typically US, appropriate object of study. But is it art? Among critics the mid-2 $20^{\text {th }}$ century New York Review of Books critic and City College of New Yorktrained social scientist Irving Howe (1920-1993) was a classic case of asking but not being able to answer this question; of groping but never grasping. In one breath he would praise the movie Double Indemnity (1944, dir. Billy Wilder) as almost art. Then in the next breath he'd damn it down as dumb because "unlike a genuine work of art which brings into play a variety of emotions and character components, [Double Indemnity] rests largely on the least individualized and most anonymous aspects of ourselves." ${ }^{86}$ Really? Wasn't Howe's reasoning a case of what Ben Franklin called: "the most exquisite folly made of wisdom spun too fine"?

Criticism all too often seeks norms, conformity. The makers themselves are more openminded and realistic than the intellectual critics. Because the makers have to be. The best is the enemy of the good. Because the industry has a long, lurid history of making both high quality and low, jewels and junk. Or as Hollywood producer Darryl F. Zanuck proclaimed: “I know audiences feed on crap, but I can't believe that we are so lacking that we cannot dish it up to them with some trace of originality!"87 


\section{American movies and "business or art?" debate}

The history of the American movie industry reveals a lot about the business-art dynamic in the USA. It was argued from the beginning of the $20^{\text {th }}$ Century both in Europe and the United States that cinema was the seventh art. The term was invented by the Italian film theoretician Ricciotto Canudo (1879-1923). Cinema synthesized space and time, was "plastic art in motion" argued Canudo, and it wove everything together in an altogether different way from the six traditional arts of music, dance, painting, sculpture, architecture, declamation (literature). ${ }^{88}$

From 1915 onward in the United States movie makers had legally claimed artistic identity. This was done for a variety of reasons, primarily to claim the US Constitution's First Amendment rights which would allow movies a greater range of creativity, i.e., freedom of speech and reduced censorship. But, beginning with the 1915 US Supreme Court case of Mutual vs. Ohio, the court ruled that motion pictures were only a business, not art, and, as such, had no First Amendment rights. For decades thereafter in Hollywood movies this Mutual vs. Ohio decision put hard and sometimes ridiculous limits on the mimetic range of US cinema.

During this era when film was legally only a business in the USA married couples in Hollywood film always slept in separate beds, while drug addiction, suicide, miscegenation, rape and incest rarely ever existed, and even Walt Disney had to remove the teats from a cartoon cow. American producer and writer David O. Selznick cynically commented on the situation: "There might have been good movies if there had been no movie industry." 89

An additional sad and silly result was that the Oscars developed as an industry award for good business and public relations, and not for artistic merit (as now happens with Prix Un Certain Regard award at Cannes). And Hollywood's Oscar award still lingers on as more of a business promotion than an artistic recognition. Cultures are spiced by paradoxes. This is a distinct American bitter-sweet flavoring. For which there's a plethora of examples: the movie Cavalcade winning the best picture Oscar in 1933 and not $42^{\text {nd }}$ Street, Marty in 1955 and not On the Waterfront, The English Patient in 1996 and not Fargo.

Although US law and citizens' groups like the Catholic League of Decency temporarily got the better of the movie business by denying the industry artistic identity in the first half of the $20^{\text {th }}$ century, this did not quell the tensions. On the contrary, film fictions fed the flames with incidents of scandal, creative subversion, and reluctant compliance. There's no business like show business. The "spurious sense of decency" imposed on the US cinema industry "backed by the police" made movies even more "sharp and clever by forcing their wit into deeper channels". ${ }^{90}$ How so and when? Well, recall the repartee of the Marx Brothers or of James Cagney and Joan Blondell as comic actorsCagney to Blondel in Blonde Crazy (1931). He: "Now, you play ball with me [...] and your worrying days will be over. She: "Yeah? How about the nights?"

Think of John Garfield, Sylvia Sidney, or Edward G. Robinson as resourceful street toughs-George Raft to Sylvia Sidney in Pick-up (1933). He: "I've been thinking..." She: "No wonder you look so worn out." The punchy come-on by Ginger Rogers in Young Man of Manhattan (1930): "Cigarette me, big boy". Or Mae West's repartee-She: "How tall are you son?" He: "Ma'am I'm six feet seven inches." She: "Let's forget the six feet and talk about the seven inches." And, of course, Joan Crawford and Bette Davis as 
simmering sex bombs-velvet voiced Bette Davis as Jezebel Julie Marsden: "This is 1852 dumplin'-1852, not the Dark Ages! Girls don't have to simper around in white just because they're not married." (Jezebel, 1938)..$^{91}$

101 Another way to deal with this situation of creating but not appearing to be creating art was to go along to get along. On screen Charles Chaplin posed as a "foolish, helpless little man who was fastidious, sensitive and romantic." ${ }^{92}$ But in real life Chaplin was a giant of the industry and a business wolf in fool's clothing. "Chaplin is no business man," quipped American producer Sam Goldwyn, "all he knows is that he can't take anything less." ${ }^{93}$ Chaplin boasted the creation of the United Artists Corporation in 1919 to maintain Hollywood's actors' freedom of artistic creativity and ability "to sell our productions on the open market and remain independent." 94 The man was a Houdini who made a slice of life and a piece of cake out of movies at the same time.

When the Breen Office created a condition of self-imposed censorship for the Motion Picture Association even more firmly in 1934, Chaplin, a consummate businessman as artist in the US market of the time, saw no insurmountable problem with this. He wrote: "I agree that censorship is necessary, but it is difficult to apply; the only suggestion I offer is that its rules be malleable and not dogmatic, and not judged on the basis of subject matter, but on good taste, intelligence and sensitive treatment." 95

But for decades the business versus art issue with regard to movies was constantly contested by the US public and in American courts. It appeared that neither local nor national regulations would give way to the legal acceptance of movies as art which would have expanded their expressive franchise. Clearly something more than Chaplin's self-serving concessions or his oh-so British call for good manners between gentlemen was needed for American movies to progress.

Finally came the groundbreaking incident of the 1948 movie L'Amore which had been banned in New York State as "sacrilege". ${ }^{96}$ When the controversy about L'Amore finally came up before the US Supreme Court in the 1952 case of Joseph Burstyn, Incorporated vs. Wilson, Commissioner of Education of New York, et al., movies in the USA were legally declared to be both a business and an art form. The 1915 decision which had legally defined them as only a business was declared null and void.

Strengthened as an art form by years of creative subversion, the liberated US film industry free of the film Production Code produced the kinds of movies that would have been impossible before: From Here to Eternity (1953), The Moon is Blue (1953), The Man With the Golden Arm (1955), Blackboard Jungle (1955), The Rose Tattoo (1955), East of Eden (1955), Baby Doll (1956), Peyton Place (1957), Island in the Sun (1957), Cat on a Hot Tin Roof (1958), Compulsion (1959), Suddenly Last Summer (1959) and Blue Denim (1959). ${ }^{97}$ William James was right, truth happens to an idea.

The time was ripe. Popular culture could confidently sell a tougher, more sensuous, and socially engaged art. With the Burstyn vs. Wilson decision the court approved what the American public had known for a long time, that-in the words of the US Supreme Court decision:

It cannot be doubted that motion pictures are a significant medium for the communication of ideas. They may affect public attitudes and behavior in a variety of ways, ranging from direct espousal of a political or social doctrine to the subtle shaping of thought which characterizes all artistic expression....The importance of motion pictures as an organ of public opinion is not lessened by the fact that they are designed to entertain as well as to inform..$^{98}$ 
Motion pictures in the first half of the American $20^{\text {th }}$ century illustrated how business and art had to evolve through different stages. With Burnstyn vs. Wilson the relation finally achieved a prosperous level beneficial to the US public, to motion picture producers, and to the host of artists who worked to make movies happen-only after a long, slow process of value disputes, change of customs, much litigation, and only by leaving behind a paradoxical legacy like the Hollywood Oscars.

As we shall now see, a similar slow but fundamental change happened with the very word business in US English, as it became richer and more liberated over time.

\section{Follow the word}

\section{Ideas follow the order of things}

Etymology is handy. The universal principle of etymology in all languages is that "words are carried over from bodies and from the properties of bodies to express the things of the mind and spirit. The order of ideas must follow the order of things." ${ }^{19}$ Meanings are buried beneath the dust of habit for most people. But they are there. Trace a rich word through time and glimpse additions, subtractions, and multiplications of meaning. Words are a lot like Russian dolls. There's the bigger, most visible and current one on the outside. While the word gets progressively compact, harder, more original and long lasting the deeper one goes back in time.

110 When one turns to etymology and typology as a way to grapple with business and art in US civilization and traces the history of each word in American English one finds little alteration of the word art but a cornucopia of variations for business; meanings of business multiply like the apprentice sorcerer's broom.

\section{Art, to begin}

111 Though there appears to be no significant, idiomatic US English use of the word art itself-artist, arty, and artsy have been enriched by American experience and personality. ${ }^{100}$ The oldest peculiar twist on this word in US English is of artist as a deliciously devious person, "an adroit rogue"-used from 1859 onward. ${ }^{101}$ This Americanism by 1903 was stretched from the illegal to the lawful, and employed to describe anyone who was specially notable for how they did something-like a "marlin spike artist" or the "low-gear artist who used to play the organ in church". In art of the American Precisionist movement (1915-1941) and in the long tradition of American scene painting one sees a triumph of art as skill. An outstanding example would be Thomas Hart Benton's 1932 painting "Arts of the West" which celebrates rifle marksmanship, poker, pitching horse shoes, taming wild horses and square dancing as arts. ${ }^{102}$

112 An air of violence boomed out with the word arty, mixing skill and fire power since arty is a US military description of artillery use blended with art that dates from the US Civil War in 1864-“Blast the bastards with arty!". And still remains valid in the language as current US online military blogs go on about how "we arty bubbas gotta stick together" ${ }^{103}$ Lastly, in the spirit of the iconoclastic 1960s, came the terms artsy-craftsy, 
arty-farty, and artsy-fartsy to describe the foolishly or pretentiously artistic-"Suzy is such a ditzy artsy-fartsy type".

113 Violence, finesse and empty boasting bare witness to a potent yet slippery thing called art as understood in American terms. Art is the picture in the museum, the sculpture in the park, and the classics in the library. But in America art also became a term of high praise for great practical ability and an articulate barb for sham. Art was not dumbed down, but democratized.

\section{To type business}

114 To trace the order of things through the almost endless accumulation of words within a civilization is to some extent a subjective collection of evidence. Drawn from a huge number of potential texts, the chosen sampling which follows about business tries to get at the evolution of this Americanized word and meaning at its most representative points and foundational moments.

One is typing a word that embodies a value. Typology provides frame and structure. To type is not to stereotype, but to seek a "means of orientation. Typology does not teach a philosophy of its own [...] [rather, types] offer a rational consistency which is rarely found in reality. But they can appear thus in reality and in historically important ways, and they have. Such constructions make it possible to determine the typological locus of a historical phenomenon"104

\section{Business of Spanish and French-nation, language, identity}

116 America was settled in 1607 in Jamestown, 1609 in Santa Fe (now New Mexico), 1620 in Plymouth (aka: Plymouth Colony, New Plymouth Colony). This first set of settlers who stuck-"root hog or die"-implanted their language along with their European ways. Key source of the dominant language by far in what would eventually become the continental United States was an Elizabethan, Early Jacobean, Anglophilic English. ${ }^{105}$

Spanish counted in the West, as did French in the Northeast, but mainly as intrusions, the enemy's lingo. The British started using siesta around 1655, from whom that sleepy word made its way to America. Otherwise there was an enormous influx of the Spanish language flowing into the United States from Central and South America. The eventual result is that American English wound up borrowing more words from Spanish than from any other language. ${ }^{106}$ But the most common Spanish words absorbed into American English did not have to do with business. They were names given by the Spanish to the geography, people, or customs of the Americas which they first located or were names for the additions which they brought-from the Spanish-derived mosquito, buffalo and sassafras to cafeteria, calaboose and machete.

118 French is a much more multi-leveled and complicated matter since its linguistic blending with British English began in 1066 with the Norman conquest of England which then transformed that 1065 Germanic language into a very Frenchified Middle English. The direct influence of French on American English was basically twofold: the language of the early French fur traders, explorers and trappers who first named New World geography, people and customs; and "dirty" French which smacked of cold feet and faint heartedness or sexual titillation-like French leave (desertion) or French letter (condom). Again, the French words absorbed from Quebec or Louisiana into American 
English have not primarily been the language of business. And the job done by the verb business would take at least three verbs from French: commercer, faire, être. ${ }^{107}$

Point being, that the language of business in America has been a very indigenous plant.

\section{Business from the 1600s till the 1960s}

Genesis of this valuable word business in American civilization starts with the Bible, the first self-help book which English-speaking people brought from Europe to colonial America. In the Authorized King James Version (1604-1611), business is all about doing your work, getting your job done. The book of Psalms speaks of fishermen as « They that go down to the sea in ships, that do business in great waters» (Psalms $107: 23$ ). Likewise John Smith, praising Virginia in his Generall Historie of 1624, used business in the sense of work, responsibilities, thus: "So then here is a place, a nurse for souldiers, a practise for mariners, a trade for marchants, a reward for the good, and that which is most of all, a businesse (most acceptable to God) to bring such poore Infidels to the knowledge of God and his holy Gospell." 108

Most potently in the King James Bible, the twelve-year old Jesus responded to his parents who have been anxiously looking for him, thought he was lost, and find him happily attending lessons in the temple, with: "How is it that ye sought me? Wist ye not that I must be about my Father's business?" (St. Luke 2:49). Like the word dream when used in American English much later on (as in Martin Luther King's celebrated "I have a dream"), used by this Anglo-American Christ, business has a spiritual dimension well above its material meaning.

Next for business in America comes the act of profitable dealings between people, in the more specific sense of give and take, trade and exchange. So that crafty Quaker the Anglo-American William Penn in his 1693 work Some Fruits of Solitude wrote that "Method goes far to prevent trouble in business: for it makes the task easy, hinders confusion, saves abundance of time, and instructs those that have business depending, both what to do and what to hope." ${ }^{109}$ (This remark anticipates Toynbee's claim of 1955 in his essay "Business School of Intellectual Action" about the well-ordered, diligent methods of business creativity.) With Penn in the late 1600s one has not yet arrived at the meaning of an institution or a system, but business is about a task you'd better organize if you want to succeed.

In the propitious year 1776 the Scottish economist Adam Smith published An Inquiry into the Nature and Causes of the Wealth of Nations. Smith's fundamental idea of business in Wealth of Nations is a philosophy of life; that business is "the accepted ideal of economic policy: the good of the greatest number" and "a sane and balanced treatment of conflicting interests, consciously adjusted to the conditions" of the time. ${ }^{110}$ As Adam Smith wrote, good business is a " 'sufficient encouragement to industry' ". ${ }^{111}$ (The systemic word capitalism, with its mixed connotations, would not come into common use until 1854. ${ }^{112}$ )

Adam Smith's understanding of business translated a transcendental notion of virtue into everyday behavior. As the American social economist Joseph Cropsey argued, Smith believed that if one could "release the people into the custody of their own passions-from which nothing can emancipate them in any case-and, with the appropriate institutional limits to contain their clashings, they will find themselves drawn by self-interest to do what is required for the good of the community." Business 
will then flourish as a positive testimony to relying upon people's internal motives rather than external compulsions. ${ }^{113}$ Following the logic of Adam Smith, his new system of capital exchange was both an everyday economic arrangement of individual investment and a social ideal. It's remained a controversial system of material and moral survival and substantial prosperity since 1776 .

Dimensions of the language grew along with economic boom and bust. By the 1830s the USA had adopted the phrase "land-office business" that meant a huge volume of sudden profitable trade and referred to the crowd of applicants that appealed to US government land offices to buy property out West. This heated excitement about business cooled down to irony in the US Gilded Age, when "funny business" (1880s) and "monkey business" (late 1800s) were coined, along with the "business end" as the sharp or dangerous end of a stick and also meaning the human genitals. ${ }^{114}$

In the US urban and industrial boom years of the 1920s business in the United States "came close to being a new religion in which the factory was the church, work was worship, and advertising [...] a theology." ${ }^{115}$ Business got sexier. By the early 1900 s in the USA "the business" meant prostitution-exactly when frigid Henry Adams in "The Dynamo and the Virgin" chapter from his autobiography claimed that the American language was sexless. ${ }^{116}$ By 1920 "business" was a pleasant word used between men for any attractive woman-as in: "I'm meeting my sweet business tonight for dinner." 117

Unchecked business enthusiasm was intensely expressed in the era's numerous exhilarating, non-fiction encomiums. These were brimming over with can-do, businessof-America-is-business cries. One would hear this pro-business, winners-not-whiners chorus loud and clear in the USA in the 1950s-when US industrialist Charles Wilson proudly boasted: "What's good for the country is good for General Motors, and vice versa"; yet again later in the 1980s Ronald Reagan era from figures like Lee Iacocca and the first black Miss America Vanessa Williams-who declared: "Success is the sweetest revenge"; and again later on from the Clinton era champions of Globalization in the 1990s-"Globalization is not something we can hold off or turn off," warned Bill Clinton, "it is the economic equivalent of a force of nature-like wind or water". ${ }^{118}$

Back in the USA 1920s a love, a heat, for business as civilization's cure-all emanated from US classics of the time such E. W. Bok's The Americanization of Edward Bok (1920), and in Henry Ford's best selling My Life and Work (1922) and Today and Tomorrow (1926). Burned in the immigrant sentiment and optimism for America's business way of life in Mary Antin's The Promised Land (1912), or in Edward E. Purinton's peppy, outstanding article "Big Ideas From Business" (1921). Business pulsed and percolated forth from advertising executive Bruce Barton's brassy concoction of self-help, Jesus and the Bible, his best-selling The Man Nobody Knows (1925). But most of all it was heard in the widelyquoted pronouncements of President Calvin Coolidge, that buttery bureaucrat at the top "distinguished for character more than for heroic achievement"-as even the official, USA's whitehouse.gov web site has admitted about Coolidge. ${ }^{119}$ For "after all," said Coolidge, "the chief business of the American people is business". ${ }^{120}$

These voices spoke with such muscle, individually or in chorus-it's as if they openly disavowed themselves of brains. Praise for the US business way of life was more than a vision of Social Darwinism, Law of the Jungle, Fordism, upward mobility or ginger talks. There was a secular spiritualism, a material mysticism at work in the need for engagement, battle, victory and trophy. 
Here was the energy that has caused each new generation of Americans to reject their "predecessors and to expect its successor to reject it," as cultural historian David M. Potter wrote in People of Plenty. ${ }^{121}$ Like the crew of Moby Dick, Americans were at work and on a creative mission at the same time.

American literature of the pre-Great Depression era did well by business-marked by William Dean Howell's triumph of decency in his masterful, sympathetic portrait of a moral businessman in The Rise of Silas Lapham (1885); in the thoroughly-valued, small town, rural individualism seen in Wila Cather's My Antonia (1918); the evangelical strain in the businessman character of Jesse Bentley in Sherwood Anderson's melancholy Winesburg, Ohio (1919); the self-indulgent romanticism and sentimental irony of Fitzgerald's The Great Gatsby (1925); in the salvation of business entrepreneurialism for the turn-of-the-century lead characters in Booth Tarkington's The Magnificent Ambersons (1918) ${ }^{122}$; and in Anzia Yezierska's hard-wrought optimism about the business of American life in Bread Givers (1925) and Red Ribbon on a White Horse (1950).

Then the worm turns. In the hard years of the Great Depression era business got reinvented to mean drug paraphernalia-"The hop head's business was crawling with roaches". It was renovated and toughened up again in the US 1940s war years to mean a beating, a harsh interrogation, to be fired or jilted-“Wow-look at Joe's black eye and broken arm-he sure got the business!”. And tangentially, but not without irony, for flirtation-“Hey, Jeany, don't look now, but that guy to your right is tryin' to give you the business". While the word's last major revival in US English was in the mid-1960s in the African-American, acronymic phrase "TCB" that Aretha Franklin belted out in her version of Otis Redding's R\&B classic "Respect". TCB: Taking Care of Business. As in Franklin's add-on lyrics: "R.E.S.P.E.C.T. / Tell you what it means to me / R.E.S.P.E.C.T. TCB! TCB!" 123 Elvis Presley even had TCB made into jewellery that he gave away and wore on a ring of diamonds that spelled it out on his fist.

\section{Conclusion}

\section{In the arena: the business of life and the American empire}

To sum up, the order of the business idea in America followed the order of things. Business was both responsible and mutually advantageous, explosive and risky, funny, funky, and seductive, and a downright driving force. It named a force which Americans have used but no one has finally measured. That increases or depletes in power but does not disappear. Business exerts a commanding energy that has drawn the American nation into its field of endeavor like no other country.

Actions speak louder than words. One meaning this collection of evidence guilty of business in US English amounts to is a non-nonsense value, a thing that performs, a verbal noun that delivers. Business in America acquires the potency of a Bergsonian, tragic-comic life force-it offers a fuller view of reality with realism in the work and idealism in the soul-to achieve all that one can. ${ }^{124}$ Or, it invites people to self-destruct. In US TV's classic "The Simpsons" (1989-present) the workaholic immigrant Apu Nahasapeemapetilon-who runs the Kwik-E-Mart-even merrily tells the armed robbers when they leave his store: Yes, "Thank you! Come again!". 
Return to a US business touchstone of the early, Republican, $20^{\text {th }}$ century and hear this bully, exuberant, can-do American attitude trumpeted in an address Teddy Roosevelt gave in Paris in 1910. That:

It is not the critic who counts; not the man who points out how the strong man stumbles, or where the doer of deeds could have done them better. The credit belongs to the man who is actually in the arena, whose face is marred by dust and sweat and blood; who strives valiantly; who errs, and comes short again and again, because there is no effort without error and shortcoming; but who does actually strive to do the deeds; who knows the great enthusiasms, the great devotions; who spends himself in a worthy cause; who at the best knows in the end the triumph of high achievement, and who at the worst, if he fails, at least fails while daring greatly, so that his place shall never be with those cold and timid souls who know neither victory nor defeat." 125

Teddy Roosevelt's call to arms to do the business of life was a necessity not to be discussed but achieved.

Then a sea change in the relation of business and art happened for America after the Second World War. In those postwar years America's international empire was established. Not as a long-lasting empire of property and land like that of the British, French, Dutch and Belgians before. But as a fragile empire of the imagination. The USA was imagined as the best of the present and the hope of the future. And the US entertainment industry fed this dream with a fury.

In 1941 American publisher and king-maker Henry R. Luce marked out in his "The American Century" editorial "an immense American internationalism. American jazz, movies, slang, machines and patented products" which had become "the only things that every community in the world recognizes in common. We are already a world power in all the trivial ways-in very human ways." ${ }^{126}$ But not so trivial, since by the late $20^{\text {th }}$ century the USA had become "what South Africa is to gold and Saudi Arabia is to oil," as the US entertainment industry brought America $\$ 5.5$ billion in foreign earnings in 1988 and more than $\$ 60$ billion by 1999, "making it the country's secondlargest net export after aerospace." ${ }^{127}$

of no small importance for the growth of the United States as an international cultural empire of the imagination has been the development of public diplomacy by the United States government since the Second World War. The relatively spontaneous social persuasions on an international scale of American culture noted by Henry Luce in his seminal "American Century" editorial of 1941 was methodically planted abroad by the USIS and the Public Affairs' departments of US embassies and consulates. By 1990 this strategy was coined as "soft power". ${ }^{128}$

European empires of the $16^{\text {th }}$ to $20^{\text {th }}$ centuries A.D. imposed their cultures without choice. The United States, in contrast, has invited and cajoled everyone into its vast Uncle Sam's Supermarket, and then invites them choose what they like. As F. Scott Fitzgerald wrote: "France was a land, England was a people, but America, having still about it that quality of an idea, was harder to utter [...] It was a willingness of the heart." ${ }^{129}$ This market place of ideas and objects, the spiritual and the material, has been all the more powerful since US business as art has honed such skills over time in selling itself. For one thing, unlike high Art, America's common culture goes to yourather than making you go to it (access rather than exegesis; like the communication difference between watching TV or going to a museum). 


\section{BIBLIOGRAPHIE}

ADAMS, Henry, The Education of Henry Adams, Boston, Houghton Mifflin C., 1918. 1997.

ANDREWS, Kevin, The Flight of Ikaros: Travels in Greece During a Civil War, London, Penguin books, 1984, orig. publ. 1959. 
ANONYMOUS, “Prabhakaran," Obituary column, The Economist, Vol. 391, No. 8632 (May 23-29, 2009) 84.

ANONYMOUS, "Slaves to some defunct economist," review of Justin Fox, The Myth of the Rational Market: A History of Risk, Reward, and Delusion on Wall Street (New York: HarperBusiness, 2009) The Economist, Vol. 391, No. 8635 (June 13, 2009) 83.

ANONYMOUS, “The Entertainment Industry”, The Economist, Dec. 23, 1989, Special supplement insert.

ANONYMOUS, “Technology and Entertainment," The Economist, Nov. 21, 1998, Special supplement insert.

ANONYMOUS, “[Review of Specimen Days and Collect].”The Mace: A Weekly Record of the Glasgow Parliamentary Debating Association, November 271882.

AUDEN. W. H., The Dyer's Hand \& Other Essays, London, Faber \& Faber, 1963.

---. Collected Shorter Poems: 1927-1957, London, Faber \& Faber, 1966.

AUGE, Paul, Larousse du XXe Siècle en six volumes, Paris, Librairie Larousse, 1931.

BENTON, William, Publ. \& Ed, The Annals of America, Vol.14 - 1916-1928, Chicago, Encyclopaedia Britannica, 1968.

BERGff, A. Scott, Max Perkins: Editor of Genius, New York: Dutton, 1978.

BERGSON, Henri. "Laughter," in: Wylie Sypher, Ed., \& Trans., Comedy, New York, Doubleday- Anchor, 1956.

BLANKENSHIP, Mark, “Dynamic Duo of Tin Pan Alley," IHT/New York Times (July 8, 2009) 8. Review of play's early July 2009 previews in New York City at Roundabout's Laura Pels Theater. See online @: “http://www.roundabouttheatre.org/pels/index.htm”.

BOSWELLl, Samuel, Boswell's Life of Johnson in Two Volumes, London, Oxford University PressHumphrey Milford, 1927.

BRIGGS, Julia, This Stage-Play World: Texts and Contexts, 1580-1625, Oxford, Oxford University Press, $1997,2^{\text {nd }}$ edn..

BURCKHARDT, Jacob, The Civilization of the Renaissance in Italy. (London: Phaidon Publs., Inc., 1950, $3^{\text {rd }}$ revised edn., trans. by S. G. C. Midlemore; orig. publ. Basel, 1860).

CANUDO, Ricciotto. The Birth of the Sixth Art, 1911.

---. Reflections on the Seventh Art, 1923; NB: Canudo's work is difficult to acquire in English; one of the better current, multi-lingual sources is the Fondazione Ricciotto Canudo. See: Libri della collana Fondazione Ricciotto Canudo, dell'editore Schena, @: http:// www.libreriauniversitaria.it/libri-collana_fondazione+ricciotto+canudo-editore_schena.htm and ABEL, Richard, Ed. French Film Theory and Criticism (Princeton U Press, 1988) 58-65, "Birth of a Sixth Art" and 291-302, "Reflections on the Seventh Art".

CARLYLE, Thomas, Critical and Miscellaneous Essays, Vol. II., London, Chapman and Hall Ltd., 1899. CASHMORE, Ellis \& ROJEK, Chris, Dictionary of Cultural Theorists, London, Arnold-Hodder Headline Group, 1999.

CHAPLIN, C., My Autobiography, London, Penguin, 1966; orig. publ. 1964.

CHRISTENSEN, Erwin O, The Index of American Design, New York \& Wash., D.C.: The Macmillan Co. \& The National Gallery of Art-Smithsonian Institution, 1950. 
CLARK, J. M., "Adam Smith and the Currents of History," The University Journal of Business, University of Chicago Press, Vol. 4, No.4, Oct., 1926, 348-369.

CLAYTON, Virginia Tuttle, STIMLINGER, Elizabeth, DOSS, Erika, \& CHOTNER, Deborah, Drawing on America's Past: Folk Art, Modernism, and the Index of American Design, Chapel Hill, N. C., University of North Carolina Press, 2003.

COCHRAN, Thomas C., ANDREWS, Wayne Eds. Concise Dictionary of American History, New York, Charles Scribner's Sons, 1962.

COHEN, T. M. \& COHEN, M. J., The Penguin Dictionary of Quotations, London, Penguin, 1960.

COOLIDGE, Calvin, Foundations of the Republic, New York, Charles Scribner's Sons, 1926.

CRACRAFT, James, ROWLAND Daniel Bruce, eds., Architectures of Russian Identity Ithaca, New York, Cornell University Press, 2004.

CROPSET, Joseph, Polity and Economy: An Interpretation of the Principles of Adam Smith Westport, Copnn., Greenwood Press 1977, reprint of orig. edn. 1957).

DEAN, John, "U.S. and European Heroism Compared," in DRUCKER, Susan J., GUMPERT, Gary, eds., Heroes in a Global World, Cresskill, New Jersey, Hampton Press, Inc. 2008, 67-97.

---, American Popular Culture La Culture Populaire Américaine, Nancy, France, Presses Universitaires de Nancy, 1992.

---. Media in the United States Since 1945, Paris: Editions Messene, 1997.

DE JOUVENEL, Bertrand, "The Treatment of Capitalism by Continental Historians," in F. A. Hayek, Ed., Capitalism and the Historians, Chicago, University of Chicago Press, 1954.

DE TOCQUEVILLE, Alexis. Democracy in America, trans. G. Lawrence, Ed. J.P. Mayer, New York: Anchor Books-Doubleday \& Co., Inc., 1969; from the last, proofed, 13th edition published during Tocqueville's lifetime, 1850 .

DIAMONSTEIN, Barbara, Handmade in America, New York, Harry N. Abrams Inc., 1983.

DIZARD, Wilson P. Jr, Inventing Public Diplomacy: The Story of the U.S. Information Agency, Boulder, Colorado, Lynne Rienner Publs., Inc., 2004.

DREISER, Theodore. Trilogy of Desire Three Novels by Theodore Dreiser, The Financier [1912] The Titan [1914] The Stoic [1945], New York: World Publishing-Times Mirror, 1972, Introd. Philip L. Gerber.

DYLAN, Bob, Chronicles, Volume One, New York, Pocket Books-Simon \& Schuster, 2004.

EMERSON, Ralph Waldo Emerson, Essays and Lectures, New York, The Library of America-Viking Press, 1983. Joel Porte, Ed..

FIEDLER, Leslie, Freaks: Myths and Images of the Secret Self, New York, Simon \& Schuster 1978.

FISK, Catherine L. Working Knowledge: Employee Innovation and the Rise of Corporate Intellectual Property, 1800-1930, Chapel Hill, University of North Carolina Press, 2009.

FITZGERALD, F. Scott. “The Swimmers,” 1929, “http://www.feedbooks.com/book/1158”. James L. W. West III, et al., Cambridge Edition of The Works of F. Scott Fitzgerald. Cambridge, UK, Cambridge University Press, 12 Vols. 1991-2009.

FLEXNER, Stuart Berg, I Hear America Talking, New York, Simon \& Schuster-Touchstone, 1976.

GILBERT, Allan H, Literary Criticism: Plato to Dryden, Detroit, Wayne State University Press, 1962. 
GORMAN, Paul R., Left Intellectuals and Popular Culture in Twentieth-Century America, Chapel Hill, N. C., University of North Carolina Press, 1996.

GRANT, Michael, The Rise of the Greeks, New York, Charles Scribner's Sons, 1987.

GUSSOW, Mal, Don't Say Yes Until I Finish Talking: A Biography of Darryl F. Zanuck, New York: Pocket Books-Simon \& Schuster, 1972.

HALLIWELL, Leslie, Halliwell's Film Guide, New York, HarperPerennial, 1996.

HARRIS, Ed., \& Ellen S. Precisionism in America 1915-1941: Reordering Reality, New York: Harry N. Abrams, 1994.

HARRIS, Neil, The Artist in American Society. The Formative Years, 1790-1860, Chicago, University of Chicago Press, $2^{\text {nd }}$ edn., 1982.

HEFFER, Simon, Moral Desperado. A Life of Thomas Carlyle, London, Phoenix Giant-Weidenfeld \& Nicolson, 1995.

HOWARD, David N., Sonic Alchemy: Visionary Music Producers and Their Maverick Recordings, Milwaukee, Wisc., Hal Leonard Corporation, 2004.

HOWE, Irving. “Notes on Mass Culture,” Politics, V. 5, Spring 1948, 120-23.

HUROK, Sol, GOODE, Ruth, Impresario: A Memoir, New York, Random House, 1946.

JACK, Chew Y., "J.S. Mill's Carrrer at the East India Company," (http://www.victorianweb.org/ philosophy/mill/career.html).

JACKSON, Andrew. "Farewell Address", March 4, 1837. Compilation of the Messages and Papers of the Presidents, vol. II, Ed. J.D. Richardson, Washington, 1908.

---. Letter, January 29, 1839, to Francis P. Blair, Jackson Papers, Library of Congress, Washington, D. C.

JAMES, William, Pragmatism and Other Essays, New York, Washington Square Press, 1963.

JOHNSON, Chalmers, “Empire of Bases”, IHTribune/NYTimes, July 14, 2009, 7.

KIPLING, Rudyard. Complete Works, New York, Doubleday, Doran \& Co., 1941. The Burwash Edition, 28 vols.

KLEIN EDLER, Steven Racek, PICKETT, Joseph P., LEONESIO, Christopher, eds. The Riverside Dictionary of Biography, Boston, Houghton Mifflin, 2005.

KUNKEL, T. Ed., Letters from the Editor: The New Yorker's Harold Ross, New York, Modern LibraryRandom House, 2000.

LARSEN, Jens P., The New Grove Haydn. New Grove Composer Biographies series, New York, W. W. Norton \& Co., 1997.

LENIN, VI, Lenin on Literature and Art, Newark, New Jersey, Wildside Press, 2008.

LEVINE, Lawrence W., Highbrow Lowbrow: The Emergence of Cultural Hierarchy in America, Cambridge: Harvard University Press, 1988.

LIGHTER, J. E., Ed., The Random House Dictionary of American Slang, NewYork, Random House, 1994. Vol. 1, A-G.

LUCE, Henry R., “The American Century,” Reader's Digest, April 1941, orig. publ. in Life, Feb. 17, 1941.

MANN, Horace, "Validictory Speech”, August 2, 1859, Antioch College, Yellow Springs, Ohio. 
MARCUSE, Herbert, Negations: Essays in Critical Theory, Boston, Beacon Press, 1968.

MAYER, J. P. Sociology of Film: Studies and Documents, London, Faber and Faber Ltd., 1946.

McLELLAN III, James E. III, DORN, Harold, Science and Technology in World History, Baltimore, The Johns Hopkins University Press, 2006, $2^{\text {nd }}$ edn..

MELVILLE, Herman, Moby Dick, New York, W. W. Norton \& Co., Inc., 1967., orig. publ. 1851.

MENCKEN, H. L., The American Language: An Inquiry into the Development of English in the United States, New York, Alfred A. Knopf, 1921, $2^{\text {nd }}$ edn..

METZI, Jamie, “Popular diplomacy”. Daedalus, March 221999.

MILLER, Douglas T., NOVAK, Marion, The Fifties: The Way We Really Were, New York, Doubleday \& Co., Inc., 1977.

MOORE, Mary T., After All, New York, Putnam, 1995.

MOOREFIELD, V., The Producer as Composer: Shaping the Sounds of Popular Music, Cambridge, Massachusetts, Massachusetts Institute of Technology Press, 2005.

MORLEY, Christopher, Poems, Garden City, New Jersey: Doubleday Doran, 1929.

NIEBUHR, Reinhold. The Reminiscences of Reinhold Niebuhr, Oral History Research Office, Columbia University, Butler Library. “Niebuhr, Reinhold Interviewee, May 1954”, pages 32-48.

NIETZSCHE, Friedrich, Nietzsche Contra Wagner, Leipzig, C. G. Naumann, 1889.

NYE, Joseph S. Jr. Bound to Lead: The Changing Nature of American Power, New York, Basic Books, 1990.

--- Soft Power: The Means to Success in World Politics, New York, Public Affairs-Perseus Books Group, 2004.

PENN, William. Some Fruits of Solitude, New York, Orion Publ. Group, 1993; orig. publ. 1693.

POLLEY, Jane. Horace Beck, et ali. Eds., American Folklore and Legend, Pleasantville, N.Y., The Reader's Digest Association Inc., 1978.

POTTER, David M., People of Plenty. Economic Abundance \& the American Character, Chicago: University of Chicago Press, 1954.

REINACH, S., Apollo: An Illustrated Manual of the History of Art Throughout the Ages, New York, Charles Scribner's Sons, $1910,3^{\text {rd }}$ ed..

REZÉ, Michel, BOWEN, Ralph, Key Words in American Life, Paris, Armand Colin, 1998, $4^{\text {th }}$ ed.

RISATTI, Howard, A Theory of Craft: Function and Aesthetic Expression, Chapel Hill, N. C., University of North Carolina Press, 2007.

ROBINSON, Harlow, The Last Impresario: The Life, Times, and Legacy of Sol Hurok, New York, Viking Press, 1994.

ROOSEVELT, Theodore, The Strenuous Life. Volume 13 of The Works of Theodore Roosevelt, National Edition. 20 Vol. set, New York: Scribners, 1926.

ROSENBERG, Bernard, WHITE, David M., eds., Mass Culture: The Popular Arts in America, New York, The Free Press, 1957.

SALTZMAN, Mark, The Tin Pan Alley Rag. book by Mark Saltzman, music \& lyrics by Irving Berlin and Scott Joplin; first produced at the Pasadena, Playhouse, Ca., 1997; to date not yet listed as published. See: The Playwrights Database - doolle.com" 
SCHLESINGER, Arthur M. Jr., The Age of Jackson, New York, Mentor-NAL, 1949.

SELDES, Gilbert, The Seven Lively Arts, New York, Harper \& Brothers Publs., 1924.

SLOANE, Eric, Tools. New York, Ballantine Books, Commemorative 4 Vol. Eric Sloan Collection, 1976, Tools orig. publ. 1964.

TARBELL, Ida, All in the Day's Work. An Autobiography, Boston, Mass.: G. K. Hall \& Co., 1985.

THUERBER, James, The Years With Ross, Boston, Little, Brown, 1959.

TOYNBEE, Arnold J. “A Business School of Intellectual Action,” Chicago Review, vol.9, $\mathrm{n}^{\circ} .1$, Spring 1955, 6-27.

WADSWORTH, William, The Poetical Works of William Wordsworth, London, Oxford University Press, 1964.

WALKER, John Ed., Halliwell's Filmgoers \& Video Viewer's Companion, New York, HarperPerennial, $1993,10^{\text {th }}$ edn.

WINCH, Donald, “Smith, Adam (bap.1723, d. 1790)”, Oxford Dictionary of National Biography, Oxford University Press, 2004.

WHITMAN, Walt. Leaves of Grass, Authoritative Texts, Prefaces, Whitman on His Art, Criticism, New York: W. W. Norton \& Co., 1973. Ed. Sculley Bradley.

WEINER, Tim. “Ahmet Ertegun, Music Executive, Dies at 83”, New York Times, December 15, 2006.

WILLKIE, Wendell L. One World, New York, Simon \& Schuster-Pocket Books, 1943.

\section{NOTES}

1. Mario Praz, The Romantic Agony (London: Fontana Library, 1960, trans. Angus Davidson; orig. publ. OUP, 1933) 22 [individuum...]; W.H.Auden, "In Memory of W. B. Yeats (d. Jan. 1939)," in: W. H. Auden, Collected Poems 1927-1957 (London: Faber \& Faber Ltd., 1966) 141-143 ["ranches of isolation..."].

2. Mel Gussow, Don't Say Yes Until I Finish Talking: A Biography of Darryl F. Zanuck (New York: Pocket Books-Simon \& Schuster, 1972; oig. publ. 1971) 85.

3. Mel Gussow, Don't Say Yes Until I Finish Talking (1972) 86.

4. John Hammond (1910-1987) produced Bob Dylan (aka: "Hammond's Folly"); Phil Spector (b. 1940) produced The Ronettes, The Crystals, The Righteous Brothers; George Martin (b.1926) produced The Beatles; Ahmet Ertegun (1923-2006) founded Atlantic Records, shaped the careers of Ray Charles, John Coltrane, Rolling Stones, among others. Quincy Jones (b.1933) produced Michael Jackson's Thriller album. All among others. A major, equivalent, US jazz figure would be Duke Ellington's aranger Billy Strayhorn (1915-1967). See: Virgil Moorefield, The Producer as Composer: Shaping the Sounds of Popular Music (2005).

5. Though Perkins was cautious about his own input. "I believe the writer [...] should always be the final judge. I have always held to that position and have sometimes seen books hurt thereby, but at least as often helped. The book belongs to the author." See: A. Scott Berg, Max Perkins: Editor of Genius (New York: Dutton, 1978); James Thurber. The Years With Ross. (Boston: Little, Brown, 1959).

6. The seven arts with cinema as the culminating "plastic art in motion" as clarified by film critic Ricciotto Canudo (1879-1923) in his "Birth of a Sixth Art" (Paris: 1911) and "Reflections on the Seventh Art" (1923). 
7. George Clapp Vaillant (1905-1945) Harvard-trained anthropologist, US diplomat and archaeologist, from: George Clapp Vaillant, Azttecs of Mexico (New York: Penguin, 1978, $2^{\text {nd }}$ revised edn. by Suzannah B. Vaillant) Ch. 9, "Craftsmanship" 149.

8. See: Erwin O. Christensen, The Index of American Design (New York \& Wash., D.C.: The Macmillan Co. \& The National Gallery of Art-Smithsonian Institution, 1950). The Index originally conceived as one of the main divisions of the Federal Art Project by painter \& pragmatist Ruth Reeves (1892-1966) and Romana Javitz. Some of the Index is online @: "http://www.nga.gov/collection/ iad/history/making5.shtm". In The Index of American Design one can look and see the craft-art meld in the business of the Pennsylvania-German Conestoga wagon of 1800; in George Lawrence's Circus Wagon of 1887-1890; Eunice W. Cook's appliqué picture of gossiping women from the nineteenth century; in the Boston Navy Yard's figureheads of the 1830s; in choice American tavern signs from the $18^{\text {th }} \& 19$ th centuries; and in the American chisel-edged broad axe that's the symbol of a whole world and but the sublime and practical "extension of a man's hand."-as noted about the American broad axe: Eric Sloane, Tools (New York: Ballantine Books, Commemorative 4 Vol. Eric Sloan collection, 1976, orig. publ. 1964) 14-17. Objects as listed in Index on, respectively, pages: 43, 156, 188, 64-66, 189, 192, 103, 44. Quote about the American broad axe: Eric Sloane, Tools (New York: Ballantine Books, Commemorative 4 Vol. Eric Sloan collection, 1976, orig. publ. 1964) 14-17. See also the recent: Virginia Tuttle Clayton, Elizabeth Stillinger, Erika Doss \& Deborah Chotner, Drawing on America's Past: Folk Art, Modernism, and the Index of American Design (Chapel Hill, N. C.: University of North Carolina Press, 2003) ; \& Howard Risatti, A Theory of Craft: Function and Aesthetic Expression (Chapel Hill, N. C.: University of North Carolina Press, 2007).

9. Along with the classic objects just mentioned from The Index of American Design, a cluster of noteworthy, late-twentieth century craft examples can be seen in the works of people such as the US weaver and manufacturer Jack Lenor Larsen "whose life bridges art and commerce," in the work of wood maker Sam Maloof, the metal smith Albert Paley and the textile maker Lia Cook.Barbara Diamonstein, Handmade in America (New York: Harry N. Abrams Inc., 1983), q. 120.

10. Cranbrook Academy of Art, Bloomfield Hills, Michigan (Detroit suburb), @: http:// www.cranbrookart.edu/Pages/AboutUs.html"; Rhode Island School of Design, @: "http:// www.risd.edu/". Cranbrook is now about 75 years old, RISD was founded in 1877.

11. From current review of Mark Saltzman's The Tin Pan Alley Rag: Mark Blankenship, "Dynamic Duo of Tin Pan Alley," IHT/New York Times, July 8, 2009, 8; a play based on this thematic conflict; whose book is by Mark Saltzman, music and lyrics by Irving Berlin and Scott Joplin, and was first produced at the Pasadena, Playhouse, Ca., 1997 and is not yet listed as published. See: The Playwrights Database-doolle.com” @: “http://www.doollee.com/Playwrightss/saltzmanmark.html".

12. S. Reinach, Apollo: An Illustrated Manual of the History of Art Throughout the Ages (New York: Charles Scribner's Sons, 1910, $3^{\text {rd }}$ edn.) 1-2. Italics in Reinach edn.

13. S. Reinach, Apollo ( 1910.) 2.

14. Arnold J. Toynbee, "A Business School of Intellectual Action," Chicago Review, Vol.9, No.1 (Spring 1955), 6-27. In text hereafter: Toynbee, followed by page number of quote.

15. All of Arnold J. Toynbee's key examples in the "business school of intellectual action" were historians, whose talent, as Ernest Renan wrote, "lies in their creating a true ensemble out of facts which are but half-truths". Ernest Renan, preface to $13^{\text {th }}$ edition of La Vie de Jesus (1863).

16. India House was the East India Company, where Mill worked as a civil servant from 1823-1858. See: Chew Yong Jack, “J.S. Mill's Carrrer at the East India Company," @: "http:// www.victorianweb.org/philosophy/mill/career.html";

17. Theodore Dreiser, Trilogy of Desire Three Novels by Theodore Dreiser The Financier [1912] The Titan [1914] The Stoic [1945] (New York: World Publishing-Times Mirror, 1972), Introd. Philip L. Gerber, 43-44. Dreiser's Cowperwood Trilogy, aka: "The Trilogy of Desire"; Charles Tyson Yerkes, 
Jr. (1837-1905), US banker, stock speculator, and mass-transit system entrepreneur; among other infamies \& achievements, Yerkes was responsible for the great Chicago elevated railroad "Loop", aka: the L tracks or L trains.

18. Anonymous, "Slaves to some defunct economist," review of Justin Fox, The Myth of the Rational Market: A History of Risk, Reward, and Delusion on Wall Street (New York: HarperBusiness, 2009) in The Economist, Vol. 391, No. 8635, June 13, 2009, 83

19. James Cracraft, Daniel Bruce Rowland, Eds., Architectures of Russian Identity (Ithaca, New York:: Cornell University Press, 2004) 156.

20. Mike Gane, "Lenin, Vladimir," in: Ellis Cashmore \& Chris Rojek, Dictionary of Cultural Theorists (London: Arnold-Hodder Headline Group, 1999) 302-304, q.304. V.I. Lenin, Lenin on Literature and Art (Newark, New Jersey: Wildside Press, 2008).

21. Herbert Marcuse, Negations: Essays in Critical Theory (Boston: Beacon Press, 1968) Ch. III "The Affirmative Character of Culture", 88-133, q. 89; orig. publ. in German in Zeitschrift fur Sozialforschung, vol. VI, 1937, trans. by Jeremy J. Shapiro.

22. James E. McLellan III, Harold Dorn, Science and Technology in World History (Baltimore: The Johns Hopkins University Press, 2006, $2^{\text {nd }}$ edn.) 352..

23. See The Museum of Broadcast Communications biography of Mary Tyler Moore @: "http:// www.museum.tv/archives/etv/M/htmlM/mooremaryt/mooremaryt.htm" and the first volume of her autobiography: After All (New York: Putnam, 1995).

24. "Roosevelt's address on The Museum of Modern Art, as printed in the Herald Tribune on May 11, 1939” ; full text @: "http://www.moma.org/research/archives/highlights/04_1939.html”.

25. Limits of space \& focus forbid longer discourse about the importance of the businessman as artist figure in Western Civilization as a whole, but Solon (circa 638-559 BC) would be a good place to start. Solon was, as scholars from Plutarch to Michael Grant have pointed out, a wonderful "combination of thinker, poet, businessman." See: Michael Grant, The Rise of the Greeks (New York: Charles Scribner's Sons, 1987) 47; \& Plutarch's life of Solon in etext format @ "http:// www.gutenberg.org/etext/674".

26. Alexis de Tocqueville, Democracy in America (New York: Viking, 1956) Vol. II, Ch. 11, "In What Spirit Americans Cultivate the Arts," 50-55, both quotes; NB: last, proofed edition of Democracy in America published during Tocqueville's lifetime was in 1850 .

27. See, e.g., listing on "The Drama" in the 1922 Roget's Thesaurus of English Words \& Phrases @: "http://www.bartleby.com/110/599.html". For Haydn: Jens Peter Larsen, The New Grove Haydn (New Grove Composer Biographies) (New York: W. W. Norton \& Co., 1997).

28. See "monstre" in: Paul Augé, Larousse du Xxe Siècle en six volumes (Paris: Librairie Larousse, 1931) tome quatrième, 954.

29. See the New York Academy of Medicine's web site: "A Telling of Wonders: Teratology in Western Medicine through 1800" @: "http://www.nyam.org/initiatives/im-histe_ter1.shtml”.

30. Leslie Fiedler, Freaks: Myths and Images of the Secret Self (New York: Simon \& Schuster 1978) 24.

31. See History's channel's "P.T.Barnum and the Birth of the Freak Show," currently online @: "http://www.youtube.com/watch?v=pgtkT8MfXAo\&feature=channel_page".

32. Without which era one would not have had contemporary movements like Pop Art, Photorealism and Hyperrealism; New wave singer-poet Patti Smith; singer-poets Bob Dylan, Bruce Springsteen; and in literature the spicy new spiritualism of popular culture in North American writers the likes of Douglas Coupland and (1961- ) and the bacchanal realism of Donna Tart (1963-).

33. Invaluable for this subject is Lawrence W. Levine, Highbrow Lowbrow: The Emergence of Cultural Hierarchy in America (Cambridge: Harvard University Press, 1988), Chapter 3 "Order, Hierarchy, and Culture," 171- 242.

34. Mark Twain, The Adventures of Huckleberry Finn, Ch. XXXIII.

35. Alexis de Tocqueville, Democracy in America, trans. G.Lawrence, Ed. J. P. Mayer (1969) 256. 
36. Andrew Jackson (1767-1845), letter, January 29, 1839, to Francis P. Blair, Jackson Papers, Library of Congress.

37. William Wordsworth, "Resolution and Independence" (aka: "The Leech Gatherer") 1802, 1807, 1. 140, in: Thomas Hutchinson, Ed., The Poetical Works of William Wordsworth (London: Oxford University Press, 1964) 155-157.

38. Andrew Jackson, Farewell address, March 4, 1837. Compilation of the Messages and Papers of the Presidents, vol. II, Ed. J.D. Richardson, Washington (1908).

39. Herman Melville, Moby Dick (1851), Ch. 26, "Knights and Squires".

40. Herman Melville, Moby Dick (1851), Ch. 107, "The Carpenter".

41. Melville, Moby Dick, Ch. 13, "Wheelbarrow".

42. Melville, Moby Dick, Ch. 72, "The Monkey Rope".

43. Thomas C. Cochran, Wayne Andrews, Eds., Concise Dictionary of American History (New York: Charles Scribner's Sons, 1962) 891; Arthur M. Schlesinger, Jr., The Age of Jackson (New York: Mentor-NAL, 1949; D. P. Geddes edn. of the 1945 orig. edn.) 66-67.

44. As detailed later on in this essay, section: “American movies and 'business or art?' debate.

45. A fourth representative thinker of the time, Matthew Arnold, pushed this opposition to total incompatibility. Middle class life that grubbed for money was hopelessly vulgar, and here America was worst of all. It had none of the truth, education, refinement and high seriousness demanded by Art and Culture. As Christopher Morley wrote about Arnold in Morley's poem "Points of View": "When Abraham Lincoln was murdered / The one thing that interested Matthew Arnold / Was that the assassin shouted in Latin / As he lept on the stage. / This convinced Matthew / That there was still hope for America." See, Christopher Morley, Poems (Garden City, New Jersey: Doubleday Doran, 1929).

46. Quotes "Aristocracy and Priesthood..." and "The Leaders of Industry..." respectively from Carlyle's Past and Present (1843), Book IV, Ch. 1, Ch. 4, online @: "http://www.gutenberg.org/ files/13534/13534.txt"; while "Literaery men... " from Carlyle's 1827 essay "The State of German Literature".

47. Simon Heffer, Moral Desperado - A Life of Thomas Carlyle (London: Phoenix Giant-Weidenfeld \& Nicolson, 1995) 229.

48. Simon Heffer, Moral Desperado (1995) 229.

49. "Wealth," from Emerson, The Conduct of Life (1860)) in: Joel Porte, Ed., Emerson, Essays and Lectures (New York: The Library of America-Viking Press, 1983) 989-1011, q. 1004.

50. "Wealth," Conduct of Life, J. Porte, Ed., Emerson, Essays (1983), 989.

51. "Wealth," Conduct of Life, J. Porte, Ed., Emerson, Essays (1983), 1005. Brook Farm was an experiment in communal living in West Roxbury, Massachusetts, 1841-47, whose members included Emerson, Margaret Fuller, Orestes Brownson, Bronson Alcott and Nathaniel Hawthorne (who partly fictionalized Brook Farm in his novel Blithdale Romance, 1852). Influenced by French Socialist Charles Fourier, Brook Farm was one of many US communes of the time which tried to create an ideal community that reconciled the worker and the thinker.

52. Bible, New Testament, Jesus, Matthew, 6:24, from the Sermon on the Mount.

53. Plato, The Republic, VI, 493 e - 494 a. See the fine English-language version: Richard W. Sterling, William C. Scott, translators, Plato The Republic (New York: W. W. Norton Co., 1985) 183.

54. Bertrand de Jouvenal, "The Treatment of Capitalism by Continental Historians," in F. A. Hayek, Ed., Capitalism and the Historians (Chicago: University of Chicago Press, 1954), relevant area: 118-120.

55. W. H. Auden, The Dyer's Hand \& Other Essays (London: Faber \& Faber, 1963), "The Virgin \& The Dynamo," 71.

56. "In Memory of W. B. Yeats (d. Jan. 1939)," in: W. H. Auden, Collected Poems 1927-1957 (London: Faber \& Faber Ltd., 1966) 141-143.

57. W. H. Auden, The Dyer's Hand (1963), "The Poet \& the City", 83. 
58. Auden, Dyer's Hand (1963), "The Virgin \& The Dynamo".

59. All quotations from Aristotle in this section, unless otherwise referenced, from: Aristotle, The Poetics, 47 a 8; 51 a 36; 54 b 8; 52 a 29, and from: E. H. Blakeney translation in Allan H. Gilbert, Literary Criticism: Plato to Dryden (Detroit: Wayne State University Press, 1962) 68-124.

60. Age-old attributed quote to Aristotle, see, e.g; T. M. \& M. J. Cohen, The Penguin Dictionary of Quotations (London: Penguin, 1960) 10, or in Bartlett's. For Nietzsche on art \& truth: Friedrich Nietzsche, Nietzsche Contra Wagner (Leipzig: C. G. Naumann, 1889), "Epilogue"-full text online @: "http://www.davemckay.co.uk/philosophy/nietzsche/nietzsche. php?name=nietzsche. 1888.nietzschecontrawagner.kaufmann.10".

61. Jacob Burkhardt, The Civilization of the Renaisance in Italy (London: Phaidon Publs., Inc., 1950, $3^{\text {rd }}$ revised edn., trans. by S. G. C. Midlemore; orig. publ. Basel, 1860).

62. Jacob Burkhardt, Civilization of the Renaisance in Italy $(1950,1860) 81$.

63. Leon Battista Alberti's motto, as cited by Burkhardt, Civilization of the Renaisance in Italy (1950, 1860) 87; Florentine architect, gymnast, novelist, mathematician, horseman, inventor of a "camera obscura" and author of the important treatise De re aedificatoria (1485).

64. Specially the products of damask, gold and silver embroidery, woodcarving and 'intarsia', marble and sandstone sculptures of arabesques, portraits in wax and jewelry in gold. See: Burkhardt, Civilization of the Renaisance in Italy $(1950,1860) 52$.

65. Carlyle, Past and Present (1843), Book IV, Ch. 1, Ch. 4, online @: “http://www.gutenberg.org/ files/13534/13534.txt".

66. See: William James, “Pragmatism” @: “http://www.gutenberg.org/etext/5116”.

67. Horace Mann, Validictory Speech, August 2, 1859, Antioch College, Yellow Springs, Ohio. See Mann's Twelve Sermons @: “http://quod.lib.umich.edu/cgi/t/text/text-idx? $\mathrm{c}=\mathrm{moa} ; \mathrm{idno}=\mathrm{AJF7064}$ ". Mann was first secretary of the Massachusetts Board of Education (1837-1848), reorganized the entire public school system and teaching methods, helped establish the first US normal school in 1839.

68. John Dean, "U.S. and European Heroism Compared," Ch. 4 in: Susan J. Drucker, Gary Gumpert, Eds., Heroes in a Global World (Cresskill, New Jersey: Hampton Press, Inc., 2008) 67-97.

69. Jane Polley, Horace Beck, et ali. Eds., American Folklore and Legend (Pleasantville, N.Y.: The Reader's Digest Association Inc., 1978) 366.

70. Ida Tarbell, All in the Day's Work - An Autobiography (Boston, Mass.: G. K. Hall \& Co., 1985; orig. publ. Macmillan, 1939) 288. This was not an uncommon perception of Henry Ford at the time, seen as man who applied a rennovative, humanistic philosophy to his industry and was understood to be an idealistic creator of automobiles who had the poet's courage to dream of better worlds.

71. Ida Tarbell, All in the Day's Work $(1985,1939) 287-296$.

72. Ida Tarbell, All in the Day's Work $(1985,1939)$ 287-296.

73. The Reminiscences of Reinhold Niebuhr, in the Oral History Collection of Columbia University, Butler Library. "Niebuhr, Reinhold Interviewee, May 1954", pages 32-48; Niebuhr lived in Detroit from 1915-1928; on the whole Niebuhr's opinion about Henry Ford was equally negative and positive, fascinated by his idiosyncrasies.

74. Michel Rezé, Ralph Bowen, Key Words in American Life (Paris: Armand Colin, 1998, $4^{\text {th }}$ edn.) 149.

75. David M. Potter, People of Plenty - Economic Abundance \& the American Character (Chicago: University of Chicago Press, 1954) 68.

76. Full quote: "The moral flabbiness born of the exclusive worship of the bitch-goddess SUCCESS. That-with the squalid cash interpretation put on the word success-is our national disease"; William James in letter of Sept. 11, 1906, to H.G. Wells.; in: The Letters of William James, vol. 2 (1920).

Transatlantica, 2 | 2010 
77. For details see at National Bureau of Economic Research Business Cycle Dating Committee, @: "http://www.nber.org/cycles/recessions.html" and a simplified version of "List of recessions in the United States" @: "http://en.wikipedia.org/wiki/ List_of_recessions_in_the_United_States".

78. Walt Whitman, Leaves of Grass, Authoritative Texts, Prefaces, Whitman on His Art, Criticism. New York: W. W. Norton \& Co., 1973. Ed. Sculley Bradley. My italics.

79. [Anonymous]. "[Review of Specimen Days and Collect]."The Mace: A Weekly Record of the Glasgow Parliamentary Debating Association (27 November 1882): 2-3, @ the Walt Whitman Archive: "http:// www.whitmanarchive.org/criticism/reviews/days/anc.00105.html". Italics mine.

80. first quote, Leaves of Grass, p. 60, 1855 edn.; second quote, Preface, p. iii, 1855 edn.; both online @ the Walt Whitman Archive: “http://whitmanarchive.org/published/LG/1855/ whole.html"

81. See "Roosevelt's address on The Museum of Modern Art, as printed in the Herald Tribune on May 11, 1939," full speech @: "http://www.moma.org/research/archives/highlights/ 04_1939.html".

82. Boswell's Life of Johnson in Two Volumes (London: Oxford University Press-Humphrey Milford, 1927) Vol. 2, 186 [1778].

83. The Social Network (dir. David Fincher, wrt. Aaron Sorkin, with Jeff Eisenberg, Rooney Mara, Andrew Garfield and Justin Timberlake, 2010); line quoted delivered by Zuckerberg character in film.

84. Philip L. Gerber, Introd. to: Theodore Dreiser, Trilogy of Desire Three Novels by Theodore Dreiser The Financier [1912] The Titan [1914] The Stoic [1945] (New York: World Publishing-Times Mirror, 1972) 43-44. Dreiser's Cowperwood Trilogy, aka: "The Trilogy of Desire”.

85. August Wilson, Ma Rainey's Black Bottom (New York: Plume-Penguin, 1985) 82-83.

86. Irving Howe, "Notes on Mass Culture," Politics, V. 5, Spring 1948, 120-123; as anthologized in: Bernard Rosenberg \& David Manning White, Eds., Mass Culture: The Popular Arts in America (New York: The Free Press, 1957) 496- 503, q. 503 and footnote 1. This issue's vitality amid the US Left has received the most critical attention, e.g., see: Paul R. Gorman, Left Intellectuals and Popular Culture in Twentieth-Century America (Chapel Hill, N. C.: University of North Carolina Press, 1996).

87. John Walker, Ed., Halliwell's Filmgoers \& Video Viewer's Companion (New York: HarperPerennial, 1993, 10 $10^{\text {th }}$ edn.) 553.

88. Canudo, Ricciotto. The Birth of the Sixth Art, 1911; Reflections on the Seventh Art, 1923; see also "http://www.gioiadelcolle.info/" - "Il portale della comunit" gioiese. In the same vein Heny R. Luce insisted on the creativity of the journalist: "Publishing is a business, but journalism never was and is not essentially a business. Nor is it a profession"-as recalled in his New York Times obituary, Feb. 28, 1967.

89. John Walker, Ed., Halliwell's Filmgoers \& Video Viewer's Companion (New York: HarperPerennial, $1993,10^{\text {th }}$ edn.) 552.

90. Gilbert Seldes, The Seven Lively Arts (New York: Harper \& Brothers Publs., 1924) 355.

91. For full credits and additional dialogue, see each film respectively at IMDB: Blond Crazy @: http://www.imdb.com/title/tt0021673/"; Mae West's IMDB page @: "http://www.imdb.com/ name/nm0922213/\#Actress". Pick-up @: "http://www.imdb.com/title/tt0024448/"; Jezebel @: "http://www.imdb.com/title/tt0030287/".

92. Contemporary critic of Chaplin in The Gold Rush (1925); John Walker, Ed., Halliwell's Filmgoers Companion (1993) 153.

93. J. Walker, Ed., Halliwell's Filmgoers Companion (1993) 154.

94. Charles Chaplin, My Autobiography (London: Penguin, 1966; orig. publ. 1964) 221.

95. Charles Chaplin, My Autobiography (1966) 429.

96. See full listing and external reviews for Rossellini's L'Amore @: “http://www.imdb.com/title/ tt0040092/" 
97. As noted, chief promoter of the new sexual frankness among US screenwriter artists was Tennessee Williams. See: Ch. 12 "Hollywood in Transition" in: Douglas T. Miller \& Marion Nowak, The Ffties: The Way We Really Were (New York: Doubleday \& Co., Inc., 1977) 309-37.

98. See full text of "Joseph Burstyn, Inc. v. Wilson 343 U.S. 495 (1952)" @: "http:// supcourt.ntis.gov/get_case.html?casename=Case\%20Name:\%20JOSEPH\%20BURSTYN,\%20INC. \%20V.\%20WILSON\%20343\%20U.S.

\%20495\%20\&searchstring=mode=casename\&cn_words1=Burstyn\&cn_words2=Wilson" and online site of US Supreme Court @: "http://www.supremecourtus.gov/”.

99. Giambattista Vico, The New Science (trans. 1968, edn of 1744) Bk. 1, para. 237-38.

100. Unless otherwise noted, definitions of artist, artsy, and arty which follow are all from: J. E. Lighter, Ed., The Random House Dictionary of American Slang (New York: Random House, 1994) Vol. $1, \mathrm{~A}-\mathrm{G}, 36$.

101. Artist as criminal is reminiscent of Dickens's character from Oliver Twist (1839) Jack Dawkin's-the Artful Dodger.

102. See: Ellen S. Harris, Ed., Precisionism in America 1915-1941: Reordering Reality (New York: Harry N. Abrams, 1994). See Thomas H. Benton "Arts of the West" currently online @: "http:// twecht.tripod.com/grapesofwrath/TheArts.jpg".

103. See: "arty bubbas gotta...” @: "http://www.armchairgeneral.com/forums/archive/ index.php/t-16731.html"

104. Max Weber, "Religious Rejections of the World and Their Directions," in: H. H. Gerth, C. Wright Mills, translators and editors, From Max Weber: Essays in Sociology (New York: Oxford University Press, 1946) 323-324.

105. Linguist H. L. Mencken stressed how forcibly the "lusty being" of the Elizabethan tongue was kept alive over the years in American, rather than British, English. See: H.L. Mencken (18801956). The American Language. 1921. 5. The General Character of American English, @: "http:// www.bartleby.com/185/5.html".

106. For example, see: Stuart Berg Flexner, I Hear America Talking (New York: Simon \& SchusterTouchstone, 1976) "Spanish" 318-324, "French" 152-155.

107. See Mencken's pages from The American Language (1921) on the Spanish and French languages and American English @, respectively: "http://www.bartleby.com/185/a7.html” and "http://www.bartleby.com/185/a6.html".

108. John Smith, The Generall Historie (1624) page 61; currently available online @: "http:// community.tncc.edu/faculty/longt/ENG241/honors/Etexts.htm". NB: in accord with contemporary use, Smith spelled the word "bisiness".

109. From his classic book of aphorisms: William Penn, Some Fruits of Solitude, no. 403 (1693).

110. J. M. Clark, "Adam Smith and the Currents of History," The University Journal of Business, University of Chicago Press, Vol. 4, No.4 (Oct., 1926), pp. 348-369, quotes: 352-53.

111. From Wealth of Nations, as quoted in Donald Winch, "Smith, Adam (bap.1723, d. 1790)" Oxford Dictionary of National Biography, Oxford University Press, 2004; online version @: "http://www.oxforddnb.com/view/article/25767".

112. See: OED \& the "Spiritus-Temporis.com" website @: "http://www.spiritus-temporis.com/ capitalism/etymology.html".

113. Cropsey, Joseph, Polity and Economy: An Interpretation of the Principles of Adam Smith (1957; reprint, Greenwood Press 1977) 49-53.

114. J. E. Lighter, Ed., The Random House Dictionary of American Slang (New York: Random House, 1994) Vol. 1, A-G, 326.-327, and Christine Ammer, The American Heritage Dictionary of Idioms (New York: Hopughton Mifflin Co., 1997) in compilation for all US idiomatic "art" and "business" definitions.

115. William Benton Publ. \& Ed., The Annals of America, Vol.14 - 1916-1928 (Chicago: Encyclopaedia Britannica, 1968) 385. 
116. Henry Adams, Ch. 25 "The Dynamo \& The Virgin," paragraph 10, in The Education of Henry Adams (1918).

117. Unless noted, examples given are my own, based on the Lighter and Ammer slang and idiom dictionaries previously cited.

118. Wilson: to a U.S. Senate committee, Jan. 1953, modified popular form from reported version in New York Times (Feb. 24, 1953); “Success is...": Vanessa Williams, attributed circa 1990; "Globalization is not..." Bill Clinton, in: WGBH documentary Commanding Heights The Battle for the World Economy producer William Cran, 2002.

119. @: "http://www.whitehouse.gov/history/presidents/cc30.html"

120. Address before the American Society of Newspaper Editors, January 17, 1925, from: Calvin Coolidge, Foundations of the Republic (New York: Charles Scribner's Sons, 1926) Ch. 20.

121. David M. Potter, People of Plenty (1954) 68.

122. Book: 1918; Pulitzer Prize: 1919; movie dir. by Orson Wells 1941.

123. "Respect" by Otis Redding (c) Warner Bros. Music Ltd., on: Aretha Franklin, 20 Greatest Hits, Atlantic CD 229241135-2, cut 2. NB: Last major revival or an on-going revival? See the 23 current definitions of "business" at the Wiki UrbanDictionary, which, unfortunately, usually blends all English-speaking definitionss; @: "http://www.urbandictionary.com/define.php?term=business" 124. Bergson: "Realism is in the work when idealism is in the soul, and [...] it is only through ideality that we can resume contact with reality," in: Henri Bergson, "Laughter," from Wylie Sypher, Ed., \& Trans., Comedy (New York: Doubleday- Anchor, 1956) 162.

125. Theodore Roosevelt, address at the Sorbonne, Paris, France, April 23, 1910.-“Citizenship in a Republic," The Strenuous Life (vol. 13 of The Works of Theodore Roosevelt, national ed.), chapter 21, p. 510 (1926). Compare Rudyard Kipling's enthusiastic poem "IF" ("If you can dream and not make dreams your master / If you can think and not make thoughts your aim. /If you can force your heart and nerve and sinew

/ To serve your turn long after they are gone, /... Yours is the Earth and everything that's in it, / And-which is more-you'll be a Man, my son!").

126. Henry R. Luce, “The American Century," Reader's Digest, April 1941, orig. publ. in Life, Feb. $17,1941$.

127. It was $\$ 5.5$ billion in 1988 currency, which equals more than $\$ 9.5$ billion in 2007 currency. See: “The Entertainment Industry," special supplement in: The Economist, December 23, 1989, 4; while for 1999 figure, see: Jamie Metzi, "Popular diplomacy", in Daedalus, March 22 1999, online @: “www.articlearchives.com/international-relations/weapons-arms-military/ 1084368-1.html” $-84 \mathrm{k}$.

128. Joseph Nye, Bound to Lead: The Changing Nature of American Power (New York: Basic Books, 1990).

129. F. Scott Fitzgerald, "The Swimmers," 1929, short story's concluding lines. See: James L. W. West III, et al., Cambridge Edition of The Works of F. Scott Fitzgerald (Cambridge, UK: Cambridge University Press, 12 Vols. 1991-2009). At the same time, since WWII another level of the issue of a global "US Empire"-or any nation's global empire-is the fact of military bases abroad. How many, how big, how powerful are a nation's military bases abroad? E.g., on Okinawa, Japan, the USA to date has 38 military bases. What is the world-wide count? What is the importance of military bases abroad in relation to the influence a nation's popular culture abroad? See: Chalmers Johnson, "Empire of Bases," IHTribune/NYTimes, July 14, 2009, 7.

130. Wilson P. Dizard, Jr., Inventing Public Diplomacy: The Story of the U.S. Information Agency (Boulder, Colorado: Lynne Rienner Publs., Inc., 2004) 223.

131. Attributed to Wilkie's conversations with Stalin when he visited Russia in the early 1940s; see: Wendell L. Willkie, One World (New York: Simon \& Schuster-Pocket Books, 1943) Ch. 4 "Our 
Ally, Russia" 42-73; and the movie about Stalin's private film projectionist: The Inner Circle (1991, dir. Andrei Konchalovsky, with Tom Hulch, Bob Hoskins, Lolita Davidovich).

132. Anonymous, "Prabhakaran," weekly Obituary column, The Economist, Vol. 391, No. 8632, May 23-29, 2009, 84.

\section{AUTEUR}

JOHN DEAN

University of Versailles 